\title{
The life history of the toxic marine dinoflagellate Protoceratium reticulatum (Gonyaulacales) in culture
}

\author{
Pablo Salgado ${ }^{\mathrm{a}, \mathrm{b}, *}$, Rosa I. Figueroa ${ }^{\mathrm{b}}$, Isabel Ramilo ${ }^{\mathrm{b}}$, Isabel Bravo ${ }^{\mathrm{b}}$ \\ a Instituto de Fomento Pesquero (IFOP), Enrique Abello 0552, Casilla 101, Punta Arenas, Chile \\ ${ }^{\mathrm{b}}$ Instituto Español de Oceanografía (IEO), Centro Oceanográfico de Vigo, Subida a Radio Faro 50, 36390, Vigo, Spain
}

\section{A R T I C L E I N F O}

\section{Article history:}

Received 27 February 2017

Received in revised form 20 July 2017

Accepted 20 July 2017

Available online $\mathrm{xxx}$

\section{Keywords:}

Life history

Longitudinal biflagellation

Protoceratium reticulatum

Sexual cycle

Planozygote and germling division

Resting cyst

\begin{abstract}
A B S T R A C T
Asexual and sexual life cycle events were studied in cultures of the toxic marine dinoflagellate Protoceratium reticulatum. Asexual division by desmoschisis was characterized morphologically and changes in DNA content were analyzed by flow cytometry. The results indicated that haploid cells with a C DNA content occurred only during the light period whereas a shift from a $C$ to a $2 \mathrm{C}$ DNA content (indicative of $\mathrm{S}$ phase) took place only during darkness. The sexual life cycle was documented by examining the mating type as well as the morphology of the sexual stages and nuclei. Gamete fusion resulted in a planozygote with two longitudinal flagella, but longitudinally biflagellated cells arising from planozygote division were also observed, so one of the daughter cells retained two longitudinal flagella while the other daughter cell lacked them. Presumed planozygotes (identified by their longitudinally biflagellated form) followed two life-cycle routes: division and encystment (resting cyst formation). Both the division of longitudinally biflagellated cells and resting cyst formation are morphologically described herein. Resting cyst formation through sexual reproduction was observed in $6.1 \%$ of crosses and followed a complex heterothallic pattern. Clonal strains underwent sexuality (homothallism for planozygote formation and division) but without the production of resting cysts. Ornamental processes of resting cysts formed from the cyst wall under an outer balloon-shaped membrane and were fully developed in $<1 \mathrm{~h}$. Obligatory dormancy period was of $\sim 4$ months. Excystment resulted in a large, rounded, pigmented, longitudinally biflagellated but motionless, thecate germling that divided by desmoschisis. Like the planozygote, the first division of the germling yielded one longitudinally biflagellated daughter cell and another without longitudinal flagella. The longitudinal biflagellation state of both sexual stages and of the first division products of these cells is discussed.
\end{abstract}

(c) 2017 Elsevier B.V. All rights reserved.

\section{Introduction}

Protoceratium reticulatum (Claparède et Lachmann) Bütschli is a phototrophic marine dinoflagellate that produces and releases yessotoxin (YTX) and its analogues (Paz et al., 2004; Suzuki et al., 2007). Yessotoxin is a marine polyether compound first isolated in 1986 from the scallop Pactinopecten yessoensis in Japan (Murata et al., 1987) and later from P. reticulatum in New Zealand (Satake et al., 1997). Since then, YTX-producing P. reticulatum has been detected worldwide, including in Spain (Paz et al., 2004), the United States (Paz et al., 2007), Japan (Satake et al., 1999), Norway (Ramstad et al., 2001), Greenland (Sala-Pérez et al., 2016), Italy

\footnotetext{
* Corresponding author at: Instituto de Fomento Pesquero (IFOP), Enrique Abello 0552, Casilla 101, Punta Arenas, Chile.

E-mail addresses: pablo.salgado@ifop.cl (P. Salgado),rosa.figueroa@vi.ieo.es
} (R.I. Figueroa), isabel.ramilo@vi.ieo.es (I. Ramilo), isabel.bravo@vi.ieo.es (I. Bravo).
(Ciminiello et al., 2003), Canada and the United Kingdom (Stobo et al., 2003), Argentina (Akselman et al., 2015), and Chile (Yasumoto and Takizawa, 1997; Álvarez et al., 2011). But, despite the extensive literature on $P$. reticulatum with respect to toxin production and detection of the dinoflagellate in plankton, very little is known about its ecology, growth, and life cycle.

Dinoflagellates are considered to have an haplontic life cycle in which haploid gametes fuse to form diploid planozygotes that can divide by meiosis or encyst (Tillmann and Hoppenrath, 2013). It was long-believed that dinoflagellate population growth was based exclusively on asexual cell division and that a sexual cycle was rare, limited to unfavorable environmental conditions and, in some species, finally leading to resting cyst formation. Nevertheless, the importance of sexuality has since been recognized as not limited to resting cyst formation, as in several dinoflagellate species zygotes have been shown to divide, bypassing the resting cyst stage (Uchida et al., 1996; Figueroa et al., 2006a, 2006b; 
Tillmann and Hoppenrath, 2013). In fact, in cultures of Alexandrium minutum, planozygotes behave like a population with an "encystment-independent" division cycle which follows a diel and lightdependent rhythm similar to that of the haploid, mitotic cycle (Figueroa et al., 2015). In addition, field data have shown growth and sexual induction rates that are much higher than those previously reported in culture (Brosnahan et al., 2014). These insights into the transitions between planktonic and benthic forms and between asexual and sexual stages have revealed the very complex life histories of dinoflagellates and that sexuality is more frequent than was previously thought. Noctiluca, with its diplontic life history (Zingmark, 1970) -though challenged by Schnepf and Drebes (1993)-, and Polykrikos kofoidii, as a diplohaplontic organism, are two exceptions to the otherwise haplontic life cycle characteristic of dinoflagellates (Tillmann and Hoppenrath, 2013), although a diplohaplontic life cycle has also been proposed for the genus Alexandrium (Figueroa et al., 2015). Even the haplontic life history of many dinoflagellates comprises a wide range of speciesspecific features, including different cyst formation modalities and mating systems, different levels of morphological differentiation among life-cycle stages, different length of the dormant phase, and different factors triggering sexual and asexual processes (Blackburn et al., 2001; Elbrächter, 2003; Gribble et al., 2009; Bravo and Figueroa, 2014).

In temperate coastal areas, the life cycle of many dinoflagellates includes dormant resting stages that allow the organisms to survive under adverse environmental conditions (Dale, 1983). Resting cysts also promote dispersal and seeding, as well as enable genetic recombination by planomeiocyte meiotic division, in addition to contributing to the seasonal succession of the species (Bravo and Figueroa, 2014). Besides the formation of resting cysts, the life cycle of several dinoflagellates includes pellicle short-term cysts (also called temporary and ecdysal cysts), which play an important role in species dynamics. In the case of $P$. reticulatum, only a spiny resting cyst [named Operculodinium centrocarpum sensu Wall (1967) in previous micropaleontological studies] has been reported, initially described by Braarud (1945) from Pleistocene cyst assemblages. Subsequent studies focused on cyst distribution and the use of $P$. reticulatum as an environmental proxy, because it undergoes distinct morphological changes in response to different salinity and temperature conditions (Mertens et al., 2011; Verleye et al., 2012; Jansson et al., 2014).

In this study, we investigated the life cycle strategy of $P$. reticulatum using southern Chilean strains phylogenetically identical to others found worldwide (Salgado et al., 2017). Studying the life history of a species is fundamental to an improved understanding of its ecology and the factors that regulate its dynamics. In Chile, as in other geographical regions, $P$. reticulatum is a component of plankton and the benthos and its spatial and temporal presence have been well-described in both environments (Seguel and Sfeir, 2010; Seguel et al., 2010; Álvarez et al., 2011;
Guzmán et al., 2015); nevertheless, the processes that determine the transitions between these life forms remain to be elucidated.

\section{Materials and methods}

\subsection{Strain isolation and maintenance}

The $P$. reticulatum strains employed in this study were collected during the development of the Red Tide Monitoring Program of Southern Chile. Ten of the 11 clonal isolates used in the present study (Table 1 ) were from Queulat Sound (St. A19N3; $-44^{\circ} 29^{\prime} 28^{\prime \prime}$, $\left.-72^{\circ} 36^{\prime} 12^{\prime \prime}\right)$, situated in the Puyuhuapi Channel, Aysén region; the other isolate was from Englefield Island (St. M29N1; $-53^{\circ} 04^{\prime} 28^{\prime \prime}$, $-71^{\circ} 49^{\prime} 38^{\prime \prime}$ ), in Otway Sound, Magallanes region. Isolates from Queulat Sound were established from the progeny of several wild resting cysts collected from surface sediments in July (austral winter) 2010. The isolate from Englefield Island was established from a seawater sample trawl in February (austral summer) 2013. Cultures of the isolates were initiated by transferring individual cells into the wells of culture plates $(8 \mathrm{~mm}$ diameter; Thermo Fisher Scientific, USA) containing $250 \mu \mathrm{L}$ of L1 medium (Guillard and Hargraves, 1993) without silicate. The medium was prepared with Atlantic seawater adjusted to a salinity of 32 by the addition of sterile MQ water (Milli-Q; Millipore, USA). The cells were grown at a temperature of $15^{\circ} \mathrm{C} \pm 1{ }^{\circ} \mathrm{C}$ and a photoperiod of $12: 12 \mathrm{~h}$ light: dark (photon flux approximately $100 \mu \mathrm{mol} \mathrm{m}^{-2} \mathrm{~s}^{-1}$ ) using white fluorescence light. Cultures were maintained in Erlenmeyer flasks filled with $50 \mathrm{~mL}$ of $\mathrm{L} 1$ medium without silicate under the abovedescribed conditions.

\subsection{Morphological characterization}

For morphological studies of the thecal plates and cell division pattern by light microscopy (LM), the cells were stained with Calcofluor white (Fluorescent Brightner 28, Sigma) (Fritz and Triemer, 1985) and observed using a Leica DMLA microscope (Leica Microsystems, Wetzlar, Germany) equipped with UV epifluorescence and an AxioCam HRc camera (Zeiss, Göttingen, Germany). Species identification and morphological comparisons among isolates were based on the descriptions in the literature. A relaxed Kofoid nomenclature system was used based on homologies between the plates of $P$. reticulatum and those of other gonyaulacoid genera. The anterior intercalary plate (1a) of the Kofoid system was considered here as homologous to the third apical plate of other gonyaulacoids because this plate can make contact with plate Po; it is therefore referred to herein as the $3^{\prime}$ plate.

For scanning electron microscopy (SEM), 3-mL samples of the cultures were grown until stationary phase. Cultures with resting cysts, produced by sexually compatible strains (PRENM $\times$ PRAY3), were fixed with glutaraldehyde at a final concentration of $4 \%$. After

Table 1

Information on isolates used in this study. Strain identification, origin, year of isolation, culture origin, and isolator.

\begin{tabular}{|c|c|c|c|c|}
\hline Isolate name & Origin & Year of isolation & Culture origin & Isolator \\
\hline PRAY1-B2 & Queulat Sound (Aysén region) & 2010 & wild resting cyst & Present work \\
\hline PRAY1-B9 & Queulat Sound (Aysén region) & 2010 & wild resting cyst & Present work \\
\hline PRAY1-B11 & Queulat Sound (Aysén region) & 2010 & wild resting cyst & Present work \\
\hline PRAY2 & Queulat Sound (Aysén region) & 2010 & wild resting cyst & Present work \\
\hline PRAY3 & Queulat Sound (Aysén region) & 2010 & wild resting cyst & Present work \\
\hline PRAY4 & Queulat Sound (Aysén region) & 2010 & wild resting cyst & Present work \\
\hline PRAY5 & Queulat Sound (Aysén region) & 2010 & wild resting cyst & Present work \\
\hline PRAY6 & Queulat Sound (Aysén region) & 2010 & wild resting cyst & Present work \\
\hline PRAY7 & Queulat Sound (Aysén region) & 2010 & wild resting cyst & Present work \\
\hline PRAY10 & Queulat Sound (Aysén region) & 2010 & wild resting cyst & Present work \\
\hline PRENM & Englefield Island (Magallanes region) & 2013 & Vegetative cell & G. Pizarro \\
\hline
\end{tabular}


a 24-h incubation at room temperature, the fixed cells were filtered, stained with $2 \%$ osmium tetroxide for $30 \mathrm{~min}$, rinsed three times with distilled water, and dehydrated in a series of $30,50,70$, 90, 95 and 100\% EtOH. They were then air-dried overnight, coated with gold using a K550 X sputter coater (Emitech Ltd., Ashford, Kent, UK), and observed with a Quanta 200 scanning electron microscope (FEI, Hillsboro, OR, USA).

\subsection{Synchronization, diel cell cycle, and asexual division}

The cell-cycle characteristics of isolates PRENM and PRAY3 were examined. The cells were incubated in L1 medium in 2-L Erlenmeyer flasks until the cultures reached a concentration of $9,000-10,000$ cells $\mathrm{mL}^{-1}$ (corresponding to the exponential growth phase). They were then synchronized by a $56-\mathrm{h}$ incubation in complete darkness, following the method of Taroncher-Oldenburg et al. (1997) and Figueroa et al. (2007). Light conditions were then restored and the cells were inoculated into fresh $\mathrm{L} 1$ medium to a concentration of approximately 3,000 cells $\mathrm{mL}^{-1}$ (1.9 L in total). Samples used in the cell cycle analyses were collected beginning $24 \mathrm{~h}$ after the inoculation to allow cell recovery and the initiation of division. For flow cytometric analyses, $50-\mathrm{mL}$ sub-samples were taken every $2 \mathrm{~h}$ for 78 and $76 \mathrm{~h}$ for the PRENM and PRAY3 cell cycle, respectively. The cells in these samples were fixed for at least 20 min with formaldehyde (final concentration of $1 \%$ ).

\subsection{Flow-cytometric analyses}

Cells from the 50-mL fixed samples were filtered through a 5.0$\mu \mathrm{m}$-pore-size membrane filter (Millipore, Ireland), resuspended in $1.5 \mathrm{~mL}$ of cold methanol, stored at $4{ }^{\circ} \mathrm{C}$ for at least $24 \mathrm{~h}$ to facilitate chlorophyll extraction, and then washed in PBS (pH 7, SigmaAldrich, St. Louis, MO, USA). The pellet was resuspended in staining solution [30 $\mu \mathrm{g}$ propidium iodide (Sigma-Aldrich) $\mathrm{mL}^{-1}$ and $100 \mathrm{mg}$ RNaseA (Sigma-Aldrich) $\mathrm{mL}^{-1}$ in PBS] and incubated for $3 \mathrm{~h}$ in darkness before the cells were analyzed with a Sony SH800Z (Sony Biotechnology Inc., Japan) flow cytometer equipped with a laser emitting at $488 \mathrm{~nm}$. Samples were run at low flux and data were acquired until at least 20,000 events had been recorded. Fluorescence emission of propidium iodide was detected at $617 \mathrm{~nm}$. ModFit LT (Verity software House, Topsham, ME, USA) was used to calculate the percentages of cells in the DNA fluorescence peaks, their ratios, and the coefficients of variation (CVs). The average of CVs was $8(\mathrm{SD}=3)$ and $7(\mathrm{SD}=2)$ for PRAY3 and PRENM strains, respectively.

\subsection{Mating type and resting cyst production}

To study the mating type of $P$. reticulatum, all clonal isolates were intercrossed and intracrossed (self-crosses) (Table 2) in duplicate wells of culture plates ( $15 \mathrm{~mm}$ diameter; Thermo Fisher
Scientific, USA) filled with $2 \mathrm{~mL}$ of $\mathrm{L} 1$ medium with no added phosphates (L1-P) (Figueroa et al., 2006a, 2006b). The wells were inoculated with exponentially growing cells $(4,000-6,000$ cells $\mathrm{mL}^{-1}$ ) to a final concentration of 800 cell $\mathrm{mL}^{-1}$ (400 cells $\mathrm{mL}^{-1}$ from each isolate). The plates were sealed with adhesive tape to prevent evaporation and incubated at $15^{\circ} \mathrm{C} \pm 1^{\circ} \mathrm{C}$ with a photoperiod of $12: 12 \mathrm{~h}$ light:dark (photon flux approximately $100 \mu \mathrm{mol}$ $\mathrm{m}^{-2} \mathrm{~s}^{-1}$ ). The cultures were checked for cyst appearance every 2 days from day 1 until day 30 after crossing. At day 30, all resting cysts were counted at $400 \times$ magnification using an inverted microscope (Axiovert Zeiss 135, Jena, Germany). Other life cycle stages present in the cultures were examined as well.

Cyst production kinetic was studied in the crossing PRENM $\times$ PRAY3. Exponentially growing cells of each isolate $(4,000-$ 6,000 cells $\mathrm{mL}^{-1}$ ) were inoculated to a final concentration of 2,000 cell $\mathrm{mL}^{-1}$ ( 1,000 cells $\mathrm{mL}^{-1}$ from each isolate) in $150 \mathrm{~mL}$ of L1-P medium in duplicate $75-\mathrm{cm}^{2}$ cell culture flasks (Corning Incorporated, Corning NY, USA). Incubation conditions were the same as described above for mating type study. The flasks were checked daily until the first resting cysts appeared and then cells and cysts were counted every 5 days; the total observation period was 1 month. The $3-\mathrm{mL}$ samples used in the cell counts were stained with Lugol solution and counted at $400 \times$ magnification using a Sedgwick-Rafter chamber and an inverted microscope.

\subsection{Study of life-cycle stages}

Different life-cycle stages (vegetative cells, gametes, presumed planozygotes, resting cysts, and germlings) of $P$. reticulatum were studied from cultures of the crossing PRENM $\times$ PRAY3, using the same inoculation methodology and incubation conditions as described for the mating type study. Motile stages were identified according to the following key characteristics: (1) vegetative cells: general morphology and one longitudinal flagellum; (2) gamete pairs: cells smaller and lighter in color than vegetative cells which are fusing by epitheca and performing a particular mating dance (rotating movements); (3) presumed planozygotes: two longitudinal flagella; (4) germlings: cells which hatched from a sexual resting cyst. All cells were randomly measured $(n=30)$ at $400 \times$ magnification, video recorded, photographed, and stained with Calcofluor (Fritz and Triemer, 1985) and SYBR green (Molecular Probes, Eugene Oregon, USA) to observe nuclear development. The staining procedure was carried out with live and fixed cells. An aliquot $(1 \mathrm{~mL})$ of live culture was stained with 1:100 SYBR green (in PBS $0.01 \mathrm{M}$, pH 7, for $20 \mathrm{~min}$ ), observed under a fluorescence inverted microscope (Axiovert Zeiss 135, Jena, Germany) at $365 \mathrm{~nm}$, video recorded, and photographed using a microscope camera (Canon EOS 5D Mark II, Japan). In addition, individual cells $(n>15)$ of each stage were washed in several drops of PBS buffer and post-fixed in ethanol:acetic acid (3:1). The cells were then picked up, washed again in PBS, stained with 1:100 SYBR

Table 2

Resting cyst (+) and planozygote (x) appearance in $P$. reticulatum crosses.

\begin{tabular}{|c|c|c|c|c|c|c|c|c|c|c|c|}
\hline & PRAY2 & PRAY5 & PRAY6 & PRAY7 & PRAY10 & PRAY3 & PRAY4 & PRAY1-B2 & PRAY1-B9 & PRAY1-B11 & PRENM \\
\hline PRAY2 & $\mathrm{x}$ & $\mathrm{x}$ & $\mathrm{x}$ & $\mathrm{x}$ & $\mathrm{x}$ & $\mathrm{x}$ & $\mathrm{x}$ & $\mathrm{x}$ & $\mathrm{x}$ & $\mathrm{x}$ & $x+$ \\
\hline PRAY5 & & $x$ & $\mathrm{x}$ & $\mathrm{x}$ & $\mathrm{x}$ & $\mathrm{x}$ & $\mathrm{x}$ & $\mathrm{x}$ & $\mathrm{x}$ & $\mathrm{x}$ & $\mathrm{x}$ \\
\hline PRAY6 & & & $\mathrm{x}$ & $\mathrm{x}$ & $\mathrm{x}$ & $\mathrm{x}$ & $\mathrm{x}$ & $\mathrm{x}$ & $\mathrm{x}$ & $\mathrm{x}$ & $\mathrm{x}$ \\
\hline PRAY7 & & & & $\mathrm{x}$ & $\mathrm{x}$ & $\mathrm{x}$ & $\mathrm{x}$ & $\mathrm{x}$ & $\mathrm{x}$ & $\mathrm{x}$ & $\mathrm{x}$ \\
\hline PRAY10 & & & & & $\mathrm{x}$ & $\mathrm{x}$ & $\mathrm{x}$ & $\mathrm{x}$ & $\mathrm{x}$ & $\mathrm{x}$ & $x+$ \\
\hline PRAY3 & & & & & & $\mathrm{x}$ & $\mathrm{x}$ & $\mathrm{x}$ & $\mathrm{x}$ & $\mathrm{x}$ & $x+$ \\
\hline PRAY4 & & & & & & & $\mathrm{x}$ & $\mathrm{x}$ & $\mathrm{x}$ & $\mathrm{x}$ & $x+$ \\
\hline PRAY1-B2 & & & & & & & & $\mathrm{x}$ & $\mathrm{x}$ & $\mathrm{x}$ & $\mathrm{x}$ \\
\hline PRAY1-B9 & & & & & & & & & $\mathrm{x}$ & $\mathrm{x}$ & $\mathrm{x}$ \\
\hline PRAY1-B11 & & & & & & & & & & $\mathrm{x}$ & $\mathrm{x}$ \\
\hline PRENM & & & & & & & & & & & $\mathrm{x}$ \\
\hline
\end{tabular}




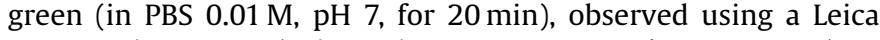
DMLA microscope (Leica Microsystems, Wetzlar, Germany) at $365 \mathrm{~nm}$, and photographed with an AxioCam HRc camera (Zeiss, Göttingen, Germany). Resting cysts were also stained with propidium iodide following the methodology described for flow cytometry.

\subsection{Division of planozygotes}

Longitudinal biflagellation is used to identify diploid motile stages, that is, planozygotes, and germlings from sexual cysts. In cultures in which recently germinated cells from sexual cysts are absent, longitudinal biflagellation is an almost consistent feature of dinoflagellate planozygotes and thus widely used to identify these sexual stages (von Stosch, 1973; McLachlan, 1993; Kremp, 2000; Parrow and Burkholder, 2004). After ensuring that germinated cysts were not present in the samples, thus ruling out the presence of germlings, swimming or settled longitudinally biflagellated cells with vegetative-like form from the PRENM $\times$ PRAY4 crossing $(n=32)$ and cells from the clonal strains PRENM $(n=12)$, PRAY3 $(n=12)$, and PRAY1-B11 $(n=12)$, obtained in the same wells and the same methodology as described for the mating type study, were individually isolated and transferred into the wells of culture plates (8 mm diameter; Thermo Fisher Scientific, USA) containing $250 \mu \mathrm{L}$
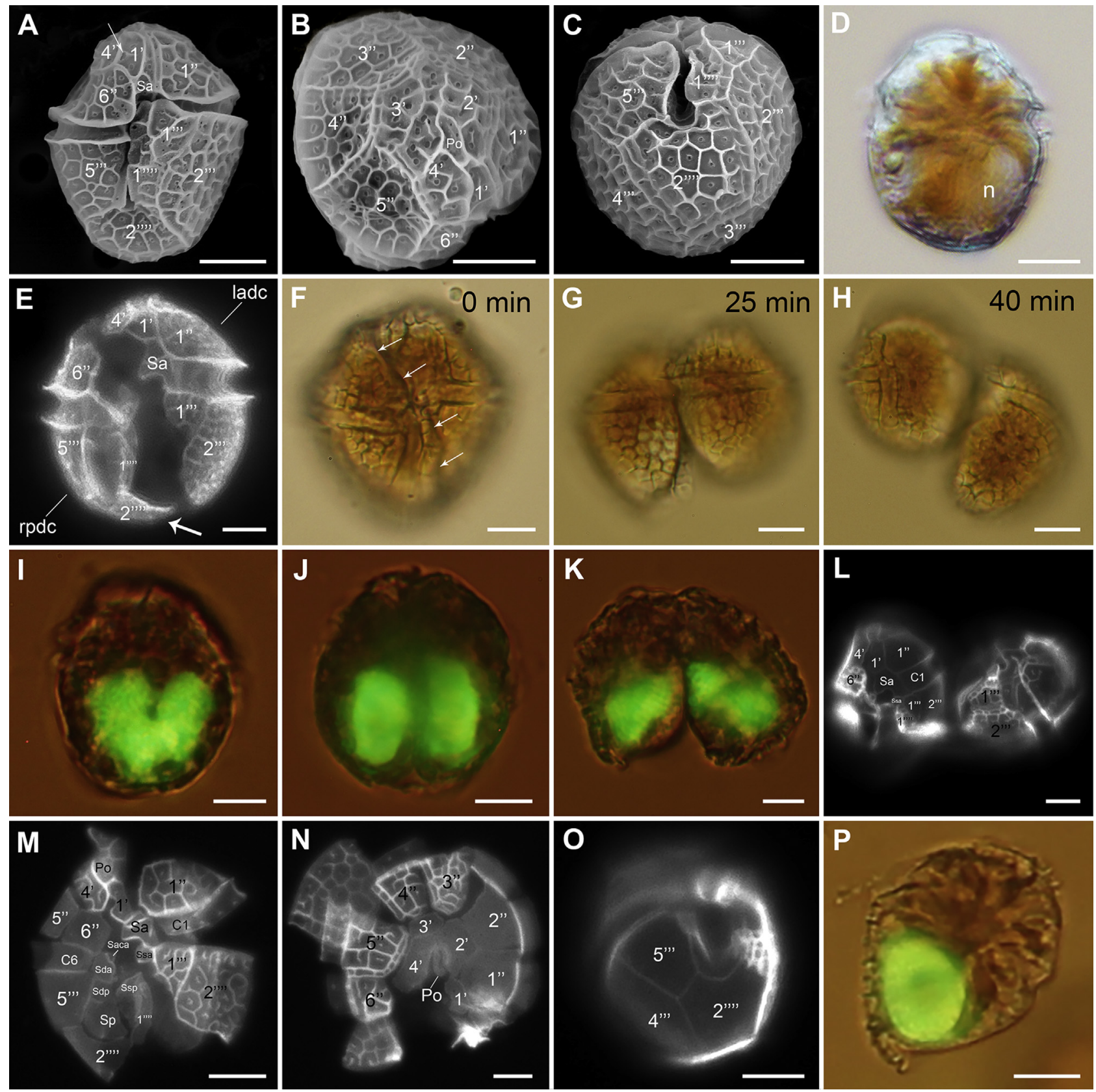

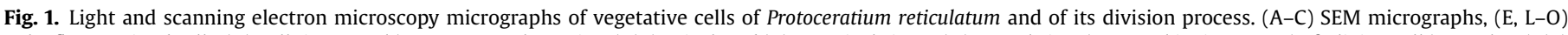

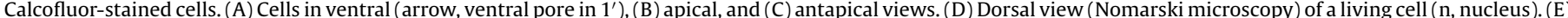

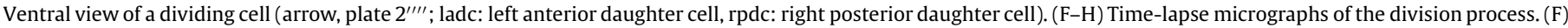

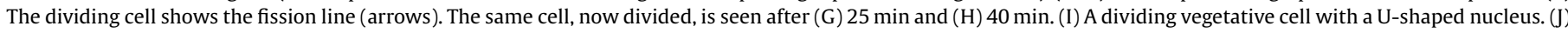

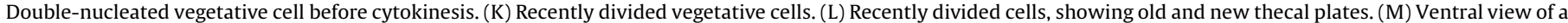

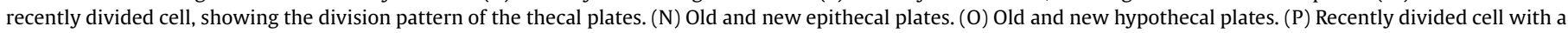
SYBR-green-stained oval nucleus. Scale bars: $10 \mu \mathrm{m}$. 
of fresh L1 medium. These were incubated as described for mating study and examined daily for 15 days to observe division, cyst formation or degradation.

As in planozygotes with a vegetative-like form, three-lobed longitudinally biflagellated cells were isolated from the PRENM $\times$ PRAY3 crossing and from clonal strain PRAY3 during the stationary growth phase. Staining these cells with SYBR green revealed the features of their nuclei.

\subsection{Dormancy period and germination}

The minimum dormancy period - defined as the minimum time from cyst formation to germination for any individual cyst- and cyst germination features were studied from the PRENM $\times$ PRAY3 cross. This cross was conducted in culture-plate wells $(35 \mathrm{~mm}$ diameter; Thermo Fisher Scientific, USA) containing $5 \mathrm{~mL}$ of L1-P medium following the same inoculation procedure used for the mating type study and incubated at $15^{\circ} \mathrm{C} \pm 1^{\circ} \mathrm{C}$ with a photoperiod of $12: 12 \mathrm{~h}$ light:dark (photon flux approximately $100 \mu \mathrm{mol} \mathrm{m}{ }^{-2}$ $\mathrm{s}^{-1}$ ). After 30 days of culture, all the cysts formed were picked up and stored in a vessel placed in the dark at $15^{\circ} \mathrm{C}$. From this batch of stored cyst, subsamples were removed for the isolation of 24-25 cysts over a period of 111 days (with the exception from day 14 to day 42 that no isolations were performed without affecting the results because we knew that dormancy period was longer than 2 months). Isolations were performed every week and between two and three weeks at the end of the isolation period. Subsamples were taken in darkness to prevent light from entering. After each isolation of cysts, the rest of the subsamples was discarded. A total of 220 cysts were isolated with micropipette under an inverted microscope (Axiovert Zeiss 135, Jena, Germany) and transferred individually into wells in 96-microwells plates ( $8 \mathrm{~mm}$ diameter; Thermo Fisher Scientific, USA) containing $250 \mu \mathrm{L}$ of L1 medium. The plates were kept at $15^{\circ} \mathrm{C} \pm 1^{\circ} \mathrm{C}$ with a photoperiod of $12: 12 \mathrm{~h}$ light:dark (photon flux approximately $100 \mu \mathrm{mol} \mathrm{m}^{-2} \mathrm{~s}^{-1}$ ). The microwells were examined for excysted cells every 2-4 days beginning on day 1 after cyst isolation and thereafter on average every 5 days over 5 months (period of isolations was 111 days and 44 days more of further observations). In addition, the wells were checked every week during a further period of 3 months to confirm the viability of the germlings and their progeny as well as the production of resting cysts in the same well from the new cell population. The dormancy period was calculated as the time in days from the middle of days of the cyst formation period (day 8 to day 30 ) to the observed peak of germinations. From our data (see Section 3.3.6 of Results) the time interval of cyst formation was estimated to last approximately 22 days (from the day 8 after crossing until the day 30 when the cysts were picked up and isolations started). Excystment was defined as the complete emergence of the protoplast from the cyst even if the germling remained non-motile. The germlings were considered viable when they experienced four consecutive divisions. Cysts and germlings $(n=30)$ were photographed and measured at $630 \times$ magnification using an Axiocam HRc digital camera (Zeiss) connected to a Leica DMLA light microscope.

\section{Results}

\subsection{Morphological and behavioral study of vegetative cells}

The Chilean isolates used in this study were morphologically characterized as $P$. reticulatum following the species description in the literature (e.g. Reinecke, 1967; /97). The most common cell type found in the cultures had shorter epitheca than hypotheca and a strong reticulation characterized by cellulosic plates with one central pore in each of their polygonal ornamentations. The plate characterization followed the formula Po, $4^{\prime}, 0 \mathrm{a}, 6^{\prime \prime}, 6 \mathrm{C}, \sim 7 \mathrm{~S}, 5^{\prime \prime \prime}, 0 \mathrm{p}$, $2^{\prime \prime \prime \prime}$, according to a relaxed Kofoid nomenclature system (Fig. $1 \mathrm{~A}-$ C). Protoceratium reticulatum vegetative cells have two flagella, one transversal and the other longitudinal. They also contain numerous golden-brown chloroplasts and an oval or lobed U-shaped nucleus located in the hypotheca dorsal part (Fig. 1D, I and P). Based on the observation of one longitudinal flagellum, the size, and the cell division pattern of this cell type it was classified as a vegetative cell. The mean ( \pm standard deviation) length and width of these vegetative cells was $35.5 \pm 2.9 \mu \mathrm{m}$ (range $30.6-40.8 \mu \mathrm{m}, n=30$ ) and $29.6 \pm 3.3 \mu \mathrm{m}$ (range 21.4-35.5 $\mu \mathrm{m}, n=30$ ), respectively.

Vegetative cells were observed undergoing two different processes: (1) division (described in Section 3.2) and (2) a progressive flattening of the protoplasm, which gave rise to a cell type with a different morphology. These latter cells featured flagella and strong dorso-ventral compression, were lighter than vegetative cells, and had a flattened nucleus located in the hypotheca. The flattened cells were observed motionless along the bottom of the culture wells but they initiated swimming when disturbed. This cell type is described in detail in Salgado et al., 2017.

\subsection{Cell cycle and division pattern of vegetative cells}

Vegetative cells of the strains PRENM and PRAY3 consistently presented the same phased pattern of DNA synthesis and cell division, for all the cycles studied. The duration of the cell cycle phases $(\mathrm{G} 1, \mathrm{~S}$, and $\mathrm{G} 2+\mathrm{M})$ were estimated according to the DNA content $(C, C \rightarrow 2 C$, and $2 C$ ) in the nuclear fluorescence histograms during the three light:dark periods. Cell cycle progression for both strains is shown in Fig. 2. The diel cell cycle was characterized by: (1) decreasing $C$ DNA peaks but increasing $\mathrm{C} \rightarrow 2 \mathrm{C}$ and $2 \mathrm{C}$ DNA peaks, which always occurred during the dark period; (2) for both

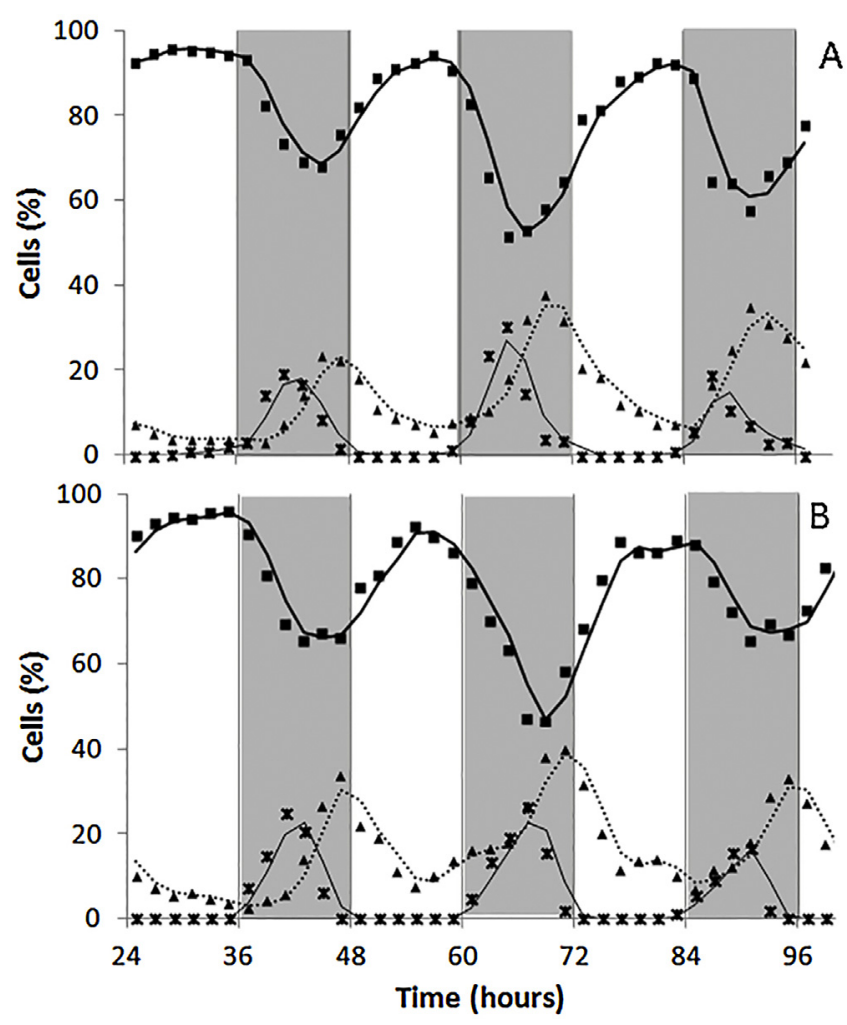

Fig. 2. Percentage of cells in the different phases of the cell cycle of strains PRENM (A) and PRAY3 (B) of P. reticulatum. Gray area represents the dark period of the diel cycle. Time corresponds to the number of hours after synchronization. DNA content: $\mathrm{C}$ (squares), $\mathrm{C} \rightarrow 2 \mathrm{C}$ (stars), and $2 \mathrm{C}$ (triangles). 

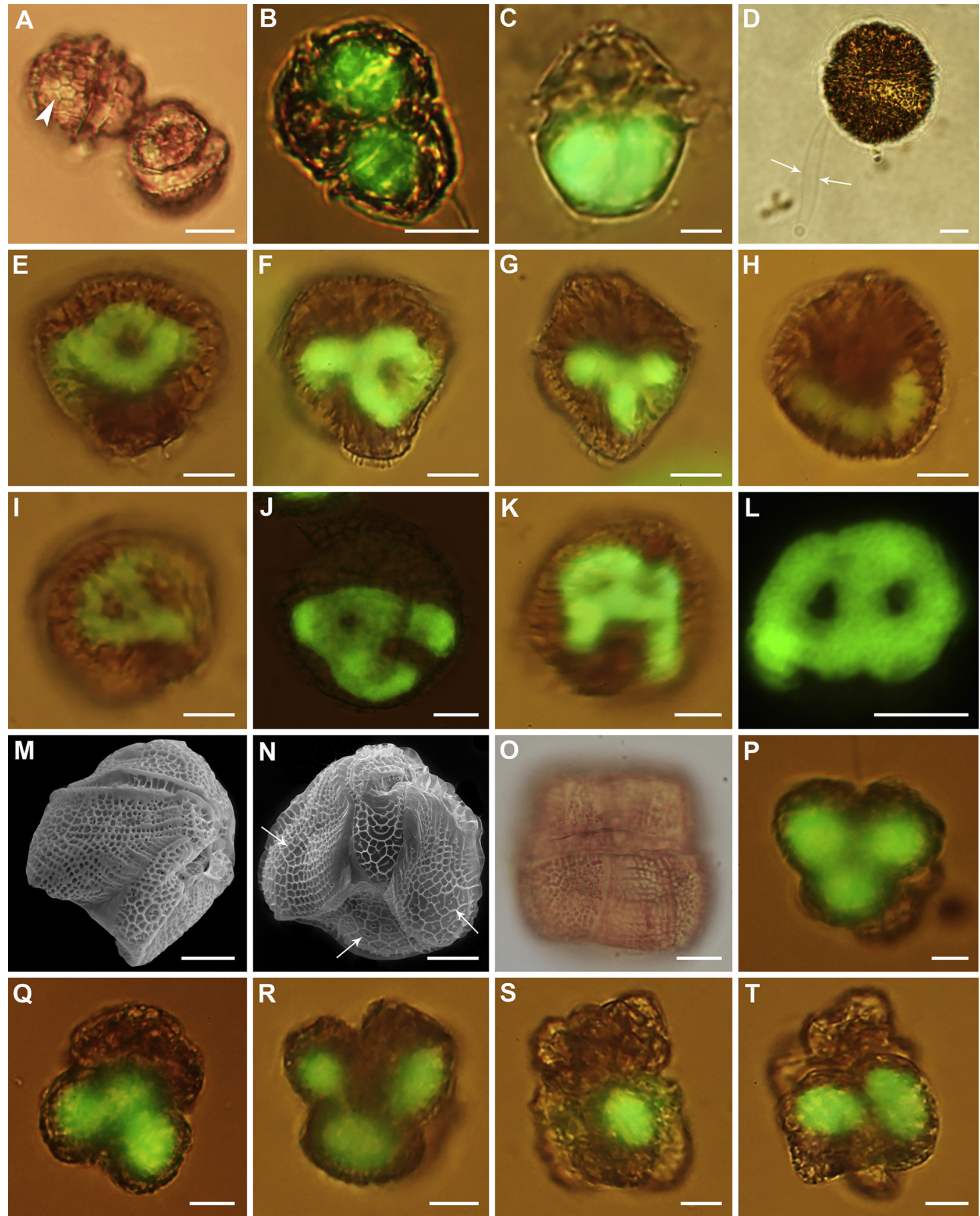

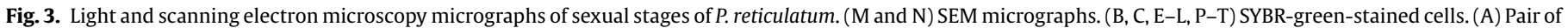

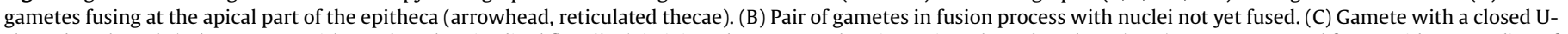

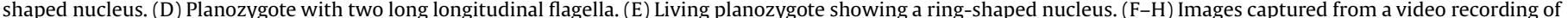

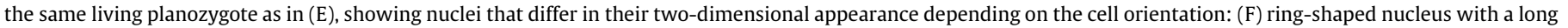

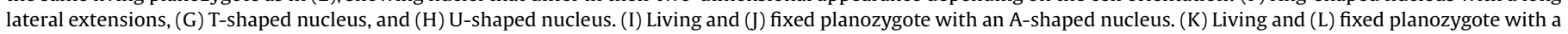

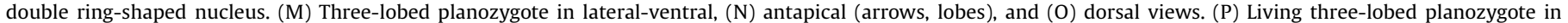

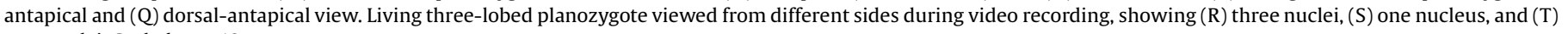
two nuclei. Scale bars: $10 \mu \mathrm{m}$. 
strains, DNA replication $(\mathrm{C} \rightarrow 2 \mathrm{C})$ that took place only during darkness in all light:dark periods studied; and (3) the decline of $2 \mathrm{C}$ cell peaks beginning at the end of the dark period and continuing during the first part of the light period.

Another characteristic of the cell cycle was that the 2C DNA content of the population never declined to as low as $0 \%$, as a variable proportion of 7-10\% and 5-7\% for the PRENM and PRAY3 strains, respectively, remained during the light period. These values well correspond to the differences in the maximums of the $2 \mathrm{C}$ and $\mathrm{C} \rightarrow 2 \mathrm{C}$ peaks.

Light microscopy examination of the division process of vegetative cells showed that desmoschisis took place along a longitudinal diagonal plane such that each daughter cell inherited part of the parental thecal plates (Fig. 1E). Formation of the daughter cells as determined microscopically lasted about $40 \mathrm{~min}$ (Fig. 1F-H). During this process, the right posterior daughter cell retained the sulcal area of the mother cell (Fig. 1E), and therefore its longitudinal flagellum, while the left anterior daughter cell lacked it. This was observed while the daughter cells were still joined and it is not known how long it took the non flagellated cell to form the flagella. The cell with the inherited flagellar apparatus was distinguished because that cell retained the antapical plate $2^{\prime \prime \prime \prime}$ when daughter cells separated (Fig. 1E). The nuclei of prekaryokinetic cells were U-shaped (Fig. 1I). Division of the nucleus yielded double-nucleated cells (Fig. 1J). Dividing cells about to split were easily recognized by the prominent fission line of the plates (Fig. 1F). In the separated cells, the thecal plates were distributed between the two daughter cells (Fig. $1 \mathrm{~K}$ and L). Recently divided cells still having only the parental half-thecae, separated rapidly. Examination of their theca revealed that division followed the characteristic division pattern of gonyaulacales. That is, the left anterior daughter cell inherited plates Po, $1^{\prime}-4^{\prime}, 1^{\prime \prime}, 2^{\prime \prime}$ (epitheca), $1^{\prime \prime \prime}-3^{\prime \prime \prime}$ (hypotheca), Sa and Ssa (sulcus) and the right posterior plates $3^{\prime \prime}-6^{\prime \prime}$ (epitheca), $4^{\prime \prime \prime}-5^{\prime \prime \prime}, 1^{\prime \prime \prime \prime}, 2^{\prime \prime \prime \prime}$ (hypotheca), Saca, Sda, Sdp, Ssp and Sp (sulcus) (Fig. 1E, M-O). Culture observations just before light period showed that recently divided cells formed new plates within a few hours $(\sim 2 \mathrm{~h})$. These new plates lacked strong reticulation and thus differed from the plates inherited from the parent (Fig. 1 L-O). Based on these characteristics, the dividing cells in the samples could be clearly identified. The nuclei of recently divided cells were oval and highly condensed (Fig. 1P).

\subsection{Sexual cycle}

\subsubsection{Mating type study}

Eleven clonal isolates of $P$. reticulatum were intercrossed and self-crossed to study sexual compatibility. Encystment through sexual reproduction was observed in $6.1 \%$ of total crosses (Table 2 ). Resting cysts appeared starting from day 7 (PRENM $\times$ PRAY3), day $8($ PRENM $\times$ PRAY4 and PRENM $\times$ PRAY10), and day $14($ PRENM $\times$ PRAY2) after crossing. All of the four positive crosses for cyst formation included the clone PRENM and the cyst yields in each of them differed. The means $( \pm S D)$ of the number of cysts for the different crosses were: $323 \pm 63$ cysts $\mathrm{mL}^{-1}$ (PRENM $\times$ PRAY2), $413 \pm 52$ cysts $\mathrm{mL}^{-1}($ PRENM $\times$ PRAY3 $), \quad 242 \pm 46{\text { cysts } \mathrm{mL}^{-1}}^{-1}$ $\left(\right.$ PRENM $\times$ PRAY4), and $98 \pm 9$ cysts $\mathrm{mL}^{-1}$ (PRENM $\times$ PRAY10). Fusing gametes and planozygotes but no resting cysts were observed in all other crosses and in all self-crosses (Table 2).

\subsubsection{Sexual stages}

Sexual stages are described for the cross PRENM $\times$ PRAY3. Although fusing gametes and planozygotes were also observed in self-crosses and other intercrosses, they were only monitored in detail from that sexual cross. The sexual cycle of $P$. reticulatum began with gametogenesis and was followed by gamete fusion (Fig. 3A and B). Gametes (Fig. 3C) were distinguished from other cells by their smaller size, pale color, fast swimming ability, and characteristic movements ("mating dance"). Gamete pairs (Fig. 3A and $B$ ) appeared on the third day after the isolates were crossed in cultures maintained without added phosphates. They also were observed in the exponential and stationary growth phases in clonal cultures (PRENM and PRAY3) with nutrient-replete medium.

The thecae of the gametes were reticulated (Fig. 3A), similar to vegetative cells. Their nuclei assumed a very closed U-shape (Fig. 3C). The mean $( \pm S D)$ length and width of the gametes was $27.8 \pm 1.8 \mu \mathrm{m}$ (range 23.7-30.5 $\mu \mathrm{m}, n=30$ ) and $22.7 \pm 1.9 \mu \mathrm{m}$ (range 19.5-26.4 $\mu \mathrm{m}, n=30$ ), respectively. Isogamy and anisogamy (in terms of different sizes) were observed, although mainly pairs of isogametes formed. Gamete fusions started mostly on the apical part of the epitheca (Fig. 3A), but sometimes from the lateral part of the hypotheca. Plasmogamy was carried out by helically swimming cells and was completed within 30-45 min $(n=6)$, producing a mobile zygote (planozygote) with two long longitudinal flagella (Fig. 3D).

Presumed planozygotes (longitudinally biflagellated cells) were frequently seen on day 4 after crossing of the isolates. We use the expression "presumed planozygote" as consequence of having observed cells with two longitudinal flagella as the first product of planozygote division (see second paragraph of Section 3.3.4), and, therefore, being not possible to confirm all longitudinally biflagellated cells as certain planozygotes. Two morphotypes were observed. The predominant form (type 1 ) had a shape similar to that of a vegetative cell, but larger [mean $( \pm S D)$ length and width of $43.9 \pm 2.5 \mu \mathrm{m}$ (range 39.9-51.9 $\mu \mathrm{m}, n=30$ ) and $37.1 \pm 2.2 \mu \mathrm{m}$ (range 33.3-42.6 $\mu \mathrm{m}, n=30$ ), respectively] and darker, with a more granular protoplasm (Fig. 3D), and a large nucleus observed in different developmental forms (see Section 3.3.3) (Fig. 3E-L). The second morphotype (type 2) was three-lobed shaped with a reticulated ornamentation different from that of vegetative cells (Fig. 3M-O), and either a large three-lobed nucleus or three oval nuclei (Fig. 3P-T). This lobed planozygote showed different levels of lobule formation (Fig. $3 \mathrm{~N}, \mathrm{P}$ and R). Swimming by these two presumed planozygote types was slower than vegetative cells and gametes. Over time, some of the presumed planozygotes with a vegetative-like form (type 1 ) became immobile, lost their flagella, and settled at the bottom of the cultures to encyst (see Section 3.3.6). By contrast, the encystment of lobed biflagellated forms (type 2) was not observed.

\subsubsection{Nuclear forms of planozygotes}

Video recordings of live culture samples of the crossing PRENM $\times$ PRAY3 stained with SYBR green provided a threedimensional view of the cell nuclei and thus reliable information on their different shapes. Three distinct nuclear forms were distinguished among the type 1 cells of the presumed planozygote (Fig. 3D). The most common form was a ring-shaped nucleus with one or two lateral extensions of different lengths (Fig. 3E and F, Video S1 in the Supplementary material), followed by an A-shaped nucleus (Fig. 3I and J), and the occasional double-ring-joined nucleus (Fig. 3K and L, Video S2 in the Supplementary material). Nonetheless, these shapes can be easily misinterpreted in photographs of fixed, SYBR-green-stained cells rather than video recording of living cells. For example, the ring-shape nucleus seen in Fig. 3E can be read as T- or U-shaped depending on the position of the cell (Fig. $3 \mathrm{G}$ and $\mathrm{H}$, respectively). In the above-described three-lobed planozygotes (type 2) (Fig. 3M-T), two nuclear forms were observed: a three-lobed nucleus (Fig. 3P and Q), and three separate nuclei (Fig. 3R). But, in the living, three-nucleated cell shown in Fig. 3R, only one (Fig. 3S) or two (Fig. 3T) nuclei can be seen when the video recording is stopped step by step, which may create misinterpretation. 


\subsubsection{Division of planozygotes}

Presumed planozygotes with vegetative-like form (type 1 ), both from the crossing of sexually compatible clones (PRENM $\times$ PRAY4) and from clonal cultures (PRENM, PRAY3, and PRAY1-B11), divided when incubated in replete medium. Among planozygotes isolated from the cross, $59 \%$ ( 19 of 32 ) divided; from those obtained from the clones $92 \%$ ( 11 of 12 ), $67 \%$ ( 8 of 12 ), and $75 \%$ (9 of 12 ) divided. There were no obvious differences in the division processes of crossed and clonal cultures. The rest of the isolated cells were degraded and no resting cysts were formed. The first division always gave rise to two daughter cells of the same size and occurred mostly on day 1 after isolation (89\%, $n=19$ ) (Fig. 4A). Although cytokinesis was not observed during the experiment of planozygote isolation because it occurred during the dark period, two different second-division timings were detected: In 68\% (13 of 19 ), the second division was synchronic and gave rise to four smaller cells on the second day after isolation. In the other 32\% (6 of $19)$, the second division was non-synchronic, since one cell divided first, producing two lighter and smaller cells, while the other larger and darker cell did not divide until the next day (Fig. 4B). Cell concentrations in the isolation wells ranged between 200 and 600 cells per well within 19 days after cell isolation of a single planozygote. The mean growth rate was one division per day ( $\mathrm{SD}=0.2, n=16$ ) during the first 5 days of the isolation, decreasing to 0.21 divisions per day during the following 7 days ( $S D=0.1$, $n=16$ ). Even though some presumed planozygotes were motile when isolated, the cells resulting from these first divisions were observed to stay immobile - but with flagella, and thus remained clustered and sometimes even in contact (Fig. 4C) for $>15$ days.

The characteristics of cytokinetic process of presumed planozygotes (type 1) were observed during routine observations of the cross PRENM $\times$ PRAY3. They featured an oblique fission line and a splitting process very similar to that described above for asexual division (desmoschisis). Likewise, thecal splitting was easily recognized because the fission line of the plates could be readily distinguished (Fig. 4D). Some of these cells were observed to present karyokinetic nuclei (Fig. 4E). As in asexual division, in planozygote division the right posterior daughter cell retained the flagellar apparatus with the two longitudinal flagella, while the other daughter cell lacked them (Fig. 4F). Likewise, the right posterior daughter cell presented transverse flagellation (although we were not able to determine accurately the number of flagella) while the other one did not.

\subsubsection{Other stages of division related to the sexual cycle}

The cell shapes and the morphology of the nuclei of the presumed three-lobed planozygotes (type 2) (Fig. 3M-T) described in the Section 3.3.2 (Sexual stages) suggest that these forms are undergoing division, although they were not isolated to follow the division progress. They were observed with different levels of lobule formation coinciding with different levels of dividing nuclei. So, the less lobed cells still presented one three-lobed nucleus (Fig. 3P and Q) whereas those with a pronounced lobulation showed three separated nuclei (Fig. 3R).

Additionally, a three-cell stage with characteristics indicative of cell division was detected in the crossings and clonal cultures. All three cells possessed theca and were joined by the antapical part of the hypotheca. Two of the cells were of equal size and the third was larger and darker. The largest cell had a U-shaped nucleus whereas the nuclei of the smaller cells were rounded. The theca of the smaller cells corresponded to that of recently divided cells, since each cell received half of the thecal plate content (Fig. 4G and $\mathrm{H}$ ). These three-cell stages settled on the bottom of the flasks and no flagella were observed.

\subsubsection{Encystment and the nuclear forms of resting cysts}

During mating type study, some of the longitudinally biflagellated cells with vegetative-like form (presumed planozygote type 1 ) that settled in the bottom of the culture plates encysted after losing their flagella (Fig. 5A). An externally transparent, balloon-
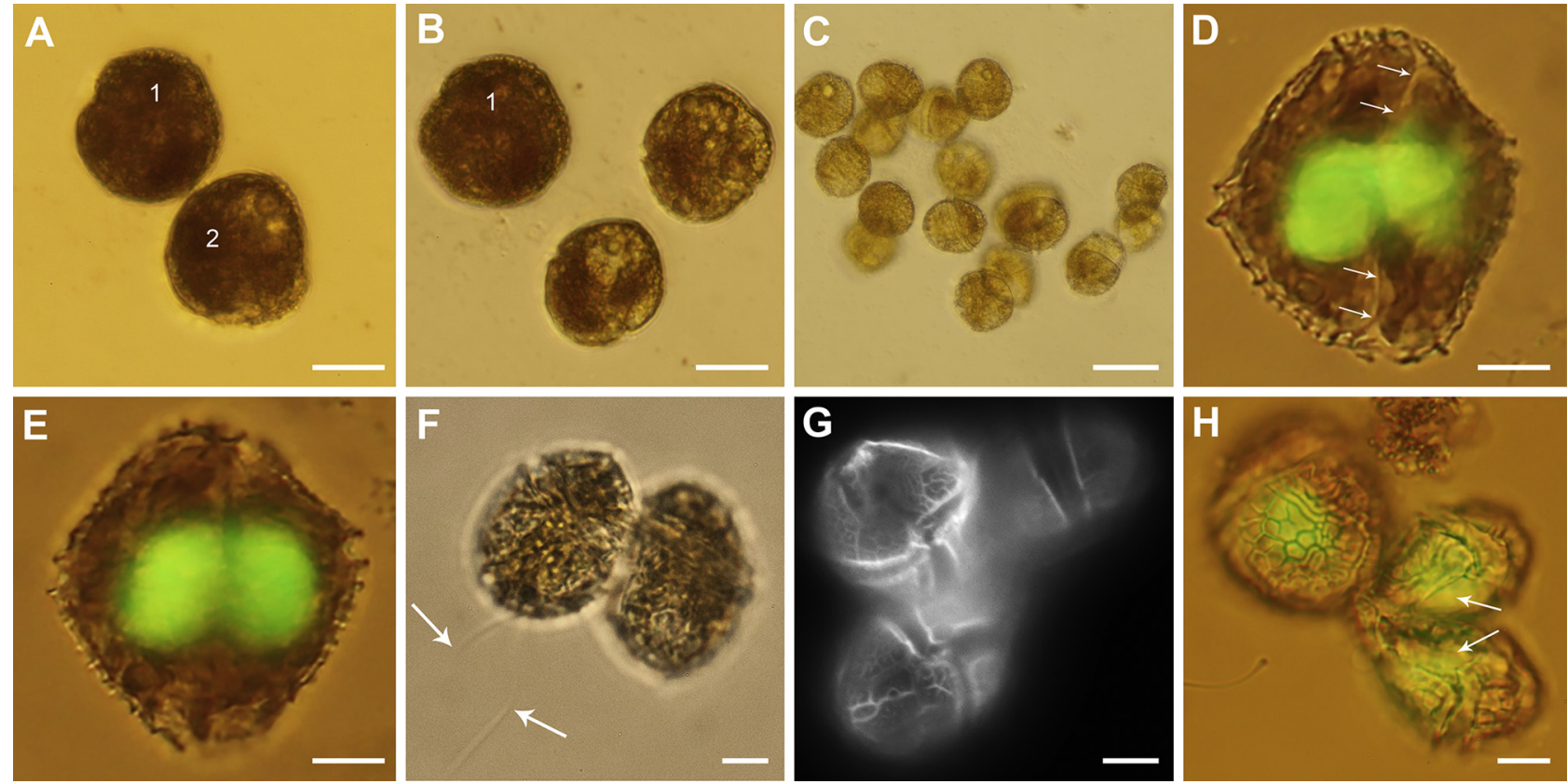

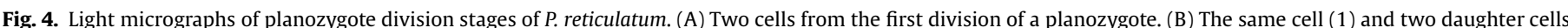

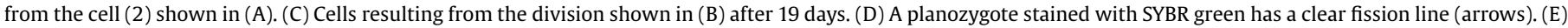

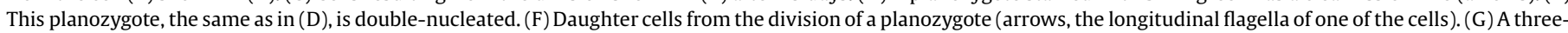

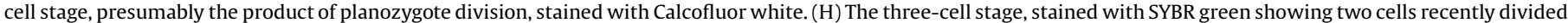

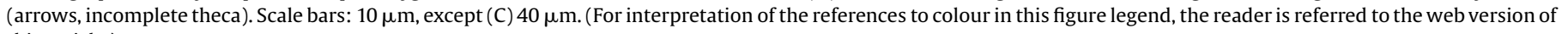
this article.) 

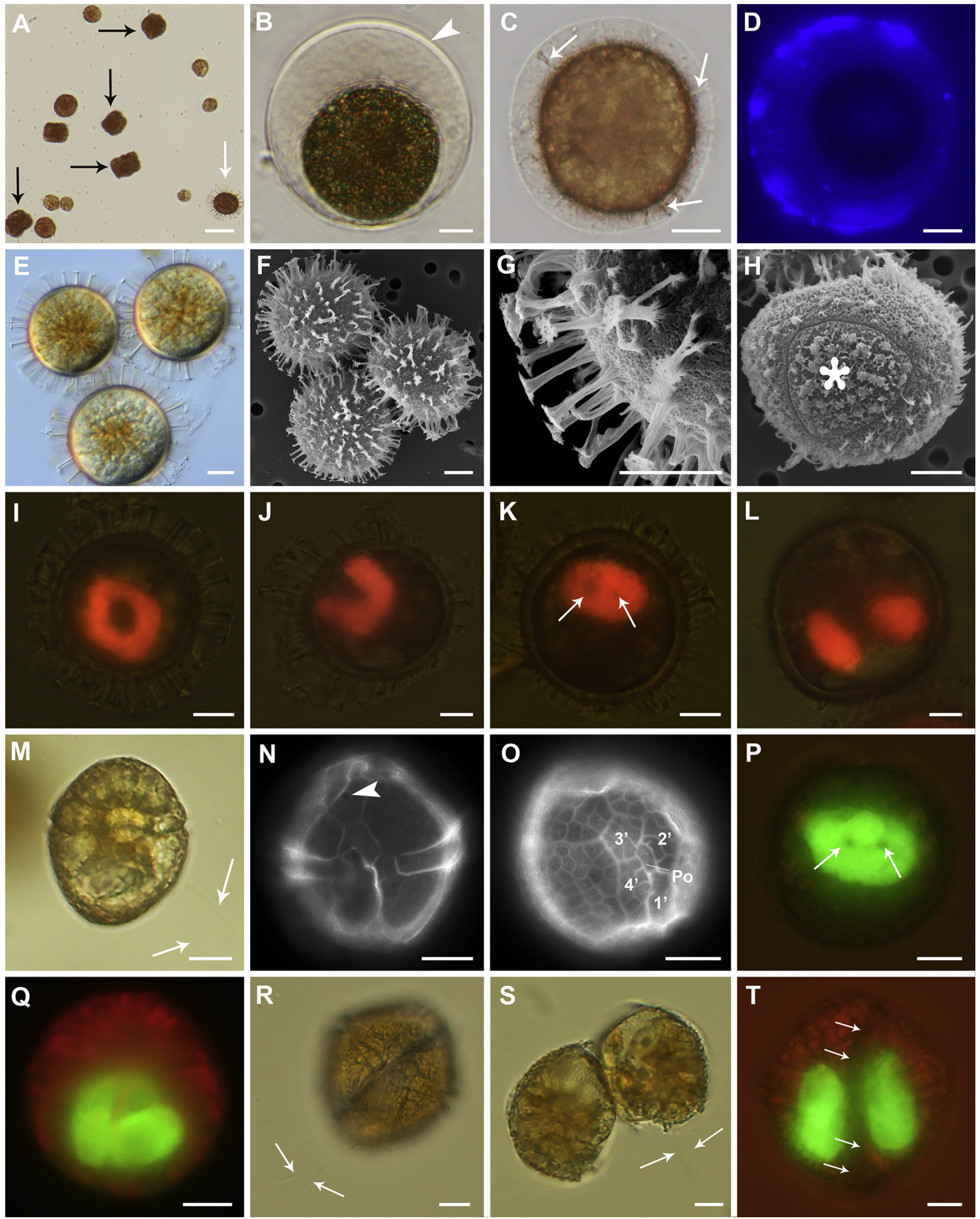

Fig. 5. Micrographs of encystment- and excystment-related stages of $P$. reticulatum. Light (A-E, I-T) and scanning electron (F-H) micrographs. (A) Longitudinally biflagellated planozygotes (black arrows) and a recently formed resting cyst (white arrow). (B) An early encysting cell showing a balloon-shaped membrane (arrowhead). (C) An encysting cell showing many processes (arrows) between the cell wall and outer membrane. (D) Cellulosic remnants stained with Calcofluor white in a recently formed cyst. (E) Resting cysts with a double wall already formed. (F) Resting cysts with processes of variable length. (G) Detail of the slender fibrillar processes, including capitate distal ends. (H) Resting cyst without processes showing a microgranulate wall and an archeopyle (asterisk). (I-L) Resting cysts stained with propidium iodide possess (I) ring-shaped and (J) U-shaped nuclei. (K) The same cyst as in (J) but observed in a different position seems to have an oval nucleus with two dark spots. (L) Cyst with two nuclei. (M) A recently germinated germling (arrows, two longitudinal flagella). (N) Thin and non-reticulated theca of a very recently hatched germling stained with Calcofluor (arrowhead, ventral pore in plate $\left.1^{\prime}\right) .(0)$ The reticulated plates of the epitheca of a thecate germling older than the one showed in previous figure. (P) Oval-shaped nucleus with two dark spots (arrows) in a germling stained with SYBR green. (Q) Closed U-shaped germling nucleus. (R) Living germling with an oblique fission line before division (arrows, two 


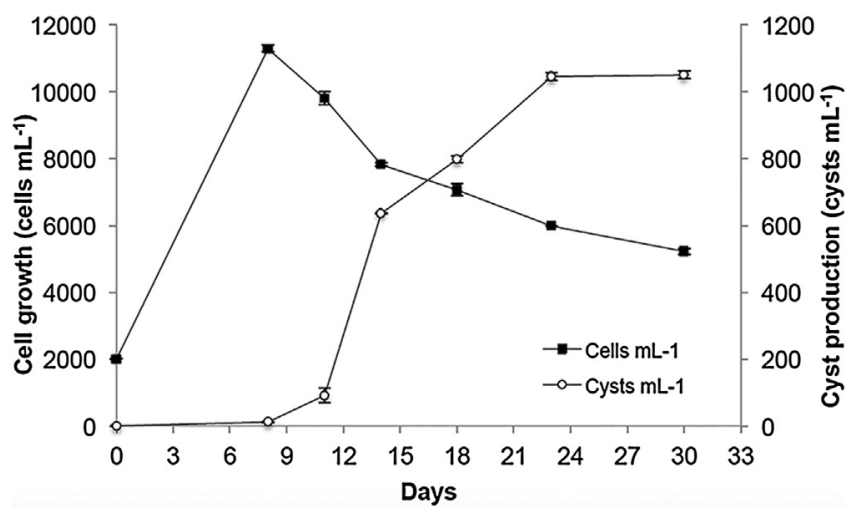

Fig. 6. Kinetics of $P$. reticulatum resting cyst formation in nutrient-depleted medium (L1-P).

shaped membrane with fluid-like contents appeared as the first step in encystment; within $45 \mathrm{~min}$ it completely covered the cell (Fig. 5B). As the transparent membrane increased in volume, many processes of different lengths appeared between the cell wall and this outer membrane (Fig. 5C). Membrane rupture typically occurred after completion of these steps, but premature rupture of the membrane prevented the further formation of cell processes. Thecal plates over the membrane were never observed when these stages were stained with Calcofluor, although cellulosic remnants were detected (Fig. 5D). Newly formed cysts had a thin wall that thickened over time until a clear double wall was evident (mean \pm SD thickness of $2.5 \pm 0.6 \mu \mathrm{m}$, range $1.3-3.9 \mu \mathrm{m}, n=30$ ) (Fig. 5E). The cysts were mainly spherical, with a mean $( \pm$ SD) diameter of $45.2 \pm 2.8 \mu \mathrm{m}$ (range 39.5-50.8 $\mu \mathrm{m}, n=25$ ), although sometimes they retained the shape of the planozygote. In addition to many transparent granules, they contained a single orangebrown accumulation body that condensed over time (Fig. 5E). The cyst wall had a microgranulate appearance and presented many slender fibrillar processes with conical bases and of variable length (mean \pm SD length of $11.8 \pm 1.8 \mu \mathrm{m}$, range 7.3-16 $\mu \mathrm{m}, n=30$ ) with capitate distal ends (Fig. $5 \mathrm{E}-\mathrm{G}$ ). Cysts without processes were also observed (Fig. $5 \mathrm{H}$ ). Its archeopyle was precingular, via the loss of a trapezoid-shaped plate, probably the plate $3^{\prime \prime}$ (Fig. 5H). The nuclei of viable resting cysts stained with propidium iodide were of variable shape (Fig. 5I-L). The two most common forms were a ring-shaped nucleus (Fig, 5I), similar to the nuclei of type 1 planozygotes, and an open U-shaped nucleus (Fig. 5J). When observed from another angle, the latter nucleus was oval-shaped, with two round dark areas (Fig. 5K). Additionally, although very scarce, binucleated cysts were detected (Fig. 5L).

A study of the kinetics of resting cyst formation in nutrientdepleted medium (L1-P) showed that the number of cysts increased from day 8 to day 30, when a maximum of 1051 cysts $\mathrm{mL}^{-1}$ was recorded. With the initiation of cyst formation (day 8), vegetative growth began to decline steadily (Fig. 6).

\subsubsection{Dormancy, excystment, and germlings}

Germination began with the exit of the germling through the cyst wall, a process that lasted $12-31 \mathrm{~min}(n=5)$. Excystment yielded a large, rounded, pigmented, and longitudinally biflagellated but motionless cell (Fig. 5M). These newly formed germlings had a wide and deep sulcal area and very thin, non-reticulated

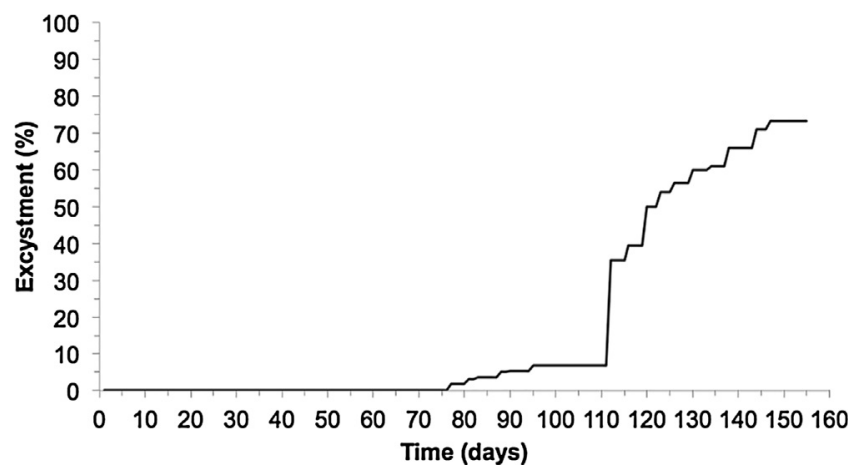

Fig. 7. Percentage of germination of $P$. reticulatum resting cysts.

thecal plates (Fig. $5 \mathrm{~N}$ ) that thickened and reticulate over the next few hours (Fig. 50). In thecate germlings older, reticulated apical plates clearly showed contact between the Po and $3^{\prime}(=1 \mathrm{a})$ plates (Fig. 50). The germling nucleus was open-U shaped, as described for resting cysts, when viewed from a different angle was ovalshaped with two dark spots (Fig. 5P). Closed-U shaped nuclei were also observed (Fig. 5Q). The germlings had a mean ( \pm SD) diameter of $46.0 \pm 3.0 \mu \mathrm{m}$ (range $40.4-53.1 \mu \mathrm{m}, n=30$ ) and divided at the bottom of culture wells by desmoschisis (Fig. 5R and S, Video S3 in the Supplementary material). Two centrally located oval nuclei were observed in dividing germlings (Fig. 5T). The first division occurred within the first $24 \mathrm{~h}$ after germination and the second division within $48 \mathrm{~h}$. As in planozygotes, in germling division one of the daughter cells retained the two longitudinal flagella but the other had no flagella (neither longitudinal nor transversal).

The obligatory dormancy period of resting cysts was estimated to be $123 \pm 11$ days. In Fig. 7 the progression of germinations of all isolations are displayed, and in Fig. 8 the germinations for all the different sets of isolated cysts are plotted separately. A 73.2\% (161 of 220) of the total resting cysts isolated germinated successfully (Fig. 7). The germination process occurred from day 77 to day 147 and the peak of germinations occurred on day 112 (Fig. 7). From all germinated cysts, $63.9 \%$ (103 of 161 ) showed germling viability and $45.6 \%$ ( 47 of 103) of the resulting cultures were capable of self-cyst production.

\section{Discussion}

The present work provides the first description of the life history of the toxic marine dinoflagellate $P$. reticulatum in culture. The morphologically and functionally distinct stages and the transitions between asexual and sexual phases are discussed next and summarized in Fig. 9.

\subsection{Asexual cycle}

Asexual division in $P$. reticulatum occurs by desmoschisis, as defined by Pfiester and Anderson (1987), in which the longitudinal diagonal fission of the mother cell yields two daughter cells that inherit part of the mother cell's thecal plates. This type of division has also been reported for other planktonic (Kokinos and Anderson, 1995; Figueroa et al., 2008a, 2015) and benthic (Hoppenrath et al., 2003; Fraga et al., 2011) gonyaulacoid

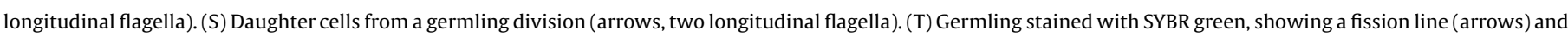

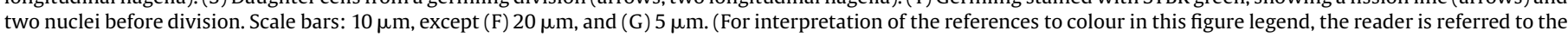
web version of this article.) 


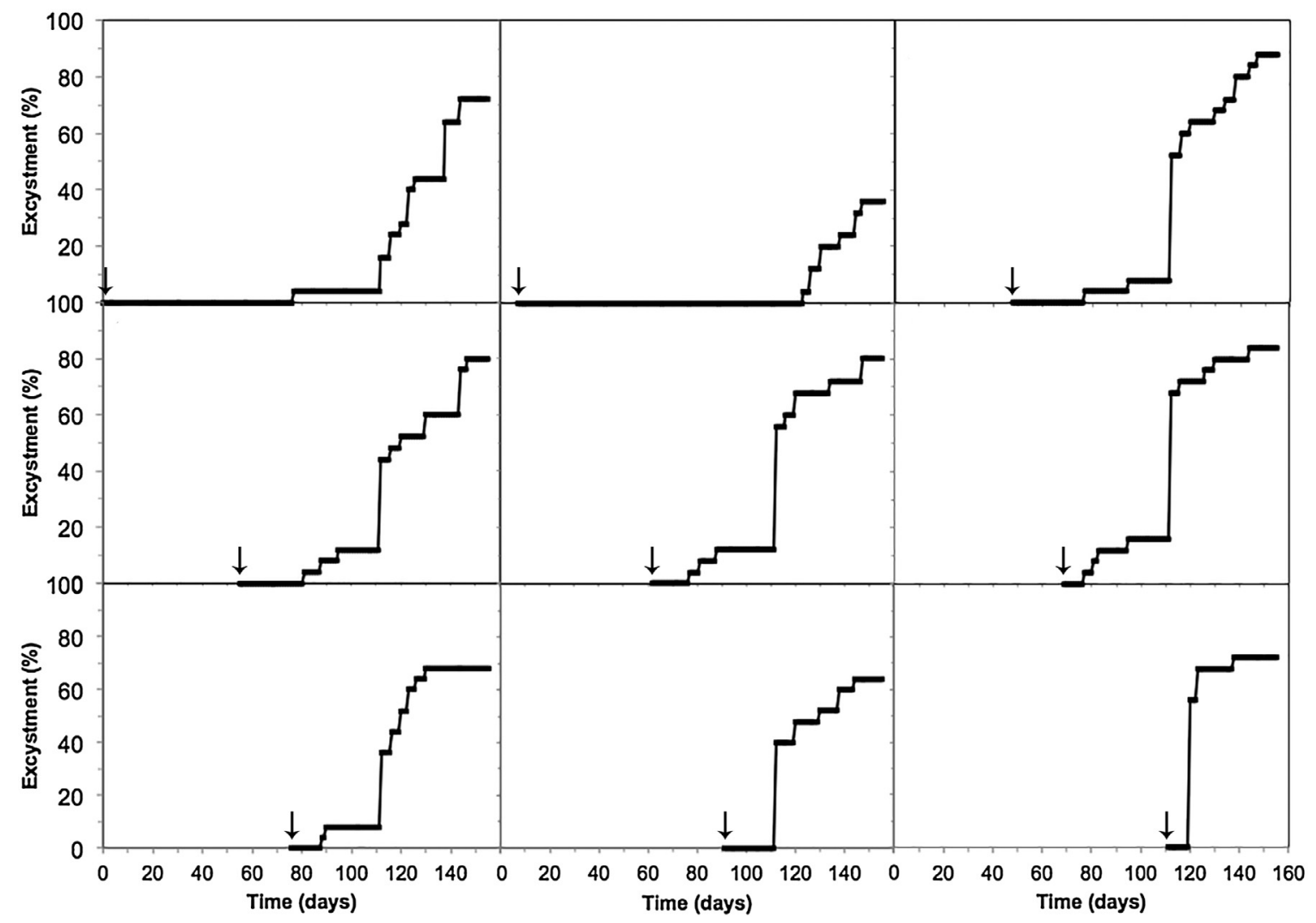

Fig. 8. Percentage of germination of each one of the different sets of P. reticulatum isolated cysts. Arrows indicate the different isolation days.

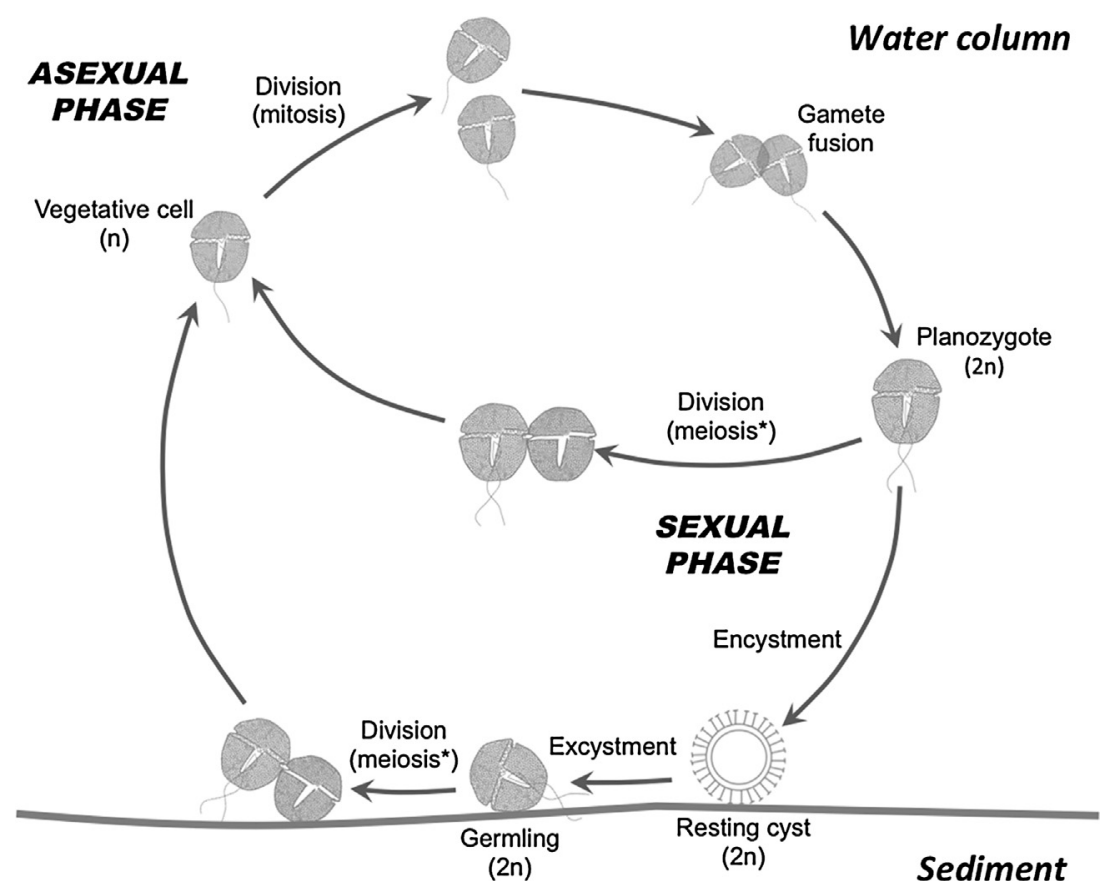

Fig. 9. Scheme of the different stages and transitions in the life cycle of P. reticulatum. *Site of meiosis according to von Stosch (1972, 1973).

dinoflagellates. Here we described dividing and recently divided cells of $P$. reticulatum, both recognizable by their theca and nuclear features. These morphologically recognizable phases of cell division facilitate detailed studies of the asexual phase of this species.
The changes in the DNA content over the course of the $P$. reticulatum cell cycle showed a circadian rhythm, as reported for other phytoplankton species (e.g. Taroncher-Oldenburg et al., 1997). Cell cycle transitions proceeded at defined and constant times of the day in our study, with DNA replication by the two 
strains occurring during darkness in all the light:dark periods studied, just as reported for the dinoflagellate Lingulodinium polyedra (Dagenais-Bellefeuille et al., 2008). In other species, DNA replication occurs, at least in part, during the light phase. For example, in cultures of the dinoflagellate $A$. minutum maintained under very similar experimental conditions, S-phase cells appeared during the light period and haploid cells with a C DNA content peaked only during a short interval within the dark period (Dapena et al., 2015). In P. reticulatum, S-phase was discrete and entirely gated during the dark period. The timing of mitosis also differed, as in A. minutum it occurred early in the dark period whereas in $P$. reticulatum it started before the onset of light. Another characteristic of the cell cycle shown in Fig. 2 was the persistence of a small portion (7-10\% for strain PRENM and 5-7\% for strain PRAY3) of cells with 2C DNA content, even when C1 reached a maximum. These cells with a $2 \mathrm{C}$ DNA content are postulated to derive from: (1) cells that had recently divided but were not yet completely separated, (2) dividing cells in G2 or M phase that were blocked by the onset of light before they entered mitosis or underwent cytokinesis, or (3) diploid cells, including fusing gametes and zygotes, that formed from sexual processes. This last alternative is supported by observations of longitudinally biflagellate cells in the clones during the cell cycle experiment. Our observations do not support the first explanation as no joined cells were seen. Therefore, at least part of the remaining 2C DNA cells were probably diploid cells. This conclusion is supported by studies of A. minutum sexual cultures, in which up to $19.4 \%$ of the $2 \mathrm{C}$ individual cells remained from one light:dark cycle to the other vs. $1-2 \%$ in clonal cultures, strongly indicating that this group of cells is mainly formed by planozygotes (Figueroa et al., 2007, 2015).

\subsection{Sexuality}

Sexual reproduction in $P$. reticulatum cultures was evidenced by the observation of gamete pairs, presumed planozygotes (longitudinally biflagellated cells), and resting cysts. While gamete pairs and cysts could be readily identified, the identification of planozygotes required careful observations. Longitudinal biflagellation has been widely used as a characteristic feature in dinoflagellate sexuality studies because, due to the similarity of planozygotes with vegetative cells, no other morphological characterization of planozygotes is available. Given that in dinoflagellates two longitudinal flagella are associated with diploidy (von Stosch, 1973; Dale, 1983), this trait was considered an appropriate criterion for the detection of sexuality assuming that after meiosis longitudinal biflagellation is lost. Yet, according to our results (discussed below) and those reported elsewhere (see review of cases in Figueroa et al., 2015), longitudinally biflagellated cells may also be primary products of planozygote and germling division. The implications of this possibility are discussed below, in the context of planozygote division.

Sexual reproduction in $P$. reticulatum was frequently observed, mainly in compatible sexual crossings in depleted medium but also in clones with nutrient-replete medium. The sexual cycle was associated with resting cyst production but also with planozygote division. A high percentage (up to 92\% in PRENM) of the presumed planozygotes divided in clonal strains, in which no cysts were formed. Whether the same behavior occurs in nature is unknown and needs to be studied. Resting cysts of $P$. reticulatum have been described in numerous reports (e.g. Wall and Dale, 1968; Alves-deSouza et al., 2008; Seguel et al., 2010; Mertens et al., 2011; Akselman et al., 2015; Sildever et al., 2015), but field studies have yet to document sexuality. Field studies that included dinoflagellate sexual stages different than those of sexual cysts are very limited, but in two reports on Gymnodinium catenatum and Alexandrium catenella (as A. fundyense) several sexual stages were described for these species (Figueroa et al., 2008b; Brosnahan et al., 2014). Whether these are related to resting cyst formation or to division processes is unknown. As reported for other species (Figueroa et al., 2006a, 2007), the presumed planozygotes of $P$. reticulatum also encysted in nutrient-poor conditions and divided when isolated into replete medium. It has been suggested that if nutrients are not critically limited, rapid sexual recombination via planozygote meiosis would be a more efficient strategy than the formation of resting stages, which instead would be appropriate in extremely nutrient-poor conditions (Figueroa et al., 2015). Moreover, the detection of a high percentage of planozygote division in clones in which no encystment occurred suggests the involvement of genetic factors.

\subsubsection{Mating type}

Dinoflagellate mating types have been traditionally classified as homothallic and heterothallic depending on their capacity to selfproduce resting cysts (homothallism) or the requirement for two compatible clonal strains to produce this sexual stage (heterothallism) (Blackburn et al., 2001). Following that definition, A. catenella has traditionally been classified as heterothallic (Yoshimatsu, 1981), and Alexandrium taylorii as homothallic (Giacobbe and Yang, 1999). Regarding this, $P$. reticulatum should be considered heterothallic because resting cysts were not formed in self-crosses. Moreover, the results were consistent with the complex heterothallic mating type behavior because a simple $(+) /(-)$ mating system cannot explain the results on resting cyst production, since cysts were not formed in the other crossings performed (intercrosses) which should be compatible if simple heterothallism occurred. This is confirmed by the result from the germling viability experiment showing that a $45.6 \%$ of the viable cultures were capable of self-cyst production (see Section 3.3.7 of Results), which rejects a simple heterothallic mating type behavior. Additionally, the compatibility of the strains crossed in the present study -always considering as 'compatible' the strains that produced cysts upon crossing them- should be considered low, as indicated by the low percentage $(6.1 \%)$ of successful crosses (Table 2). However, the lack of cyst formation by dinoflagellates cannot be considered as evidence for a lack of sexual reproduction (Montresor et al., 2004). Based on previously described levels of sexual compatibility (Destombe and Cembella, 1990; Blackburn et al., 2001), including gamete recognition, planozygote and cyst formation, meiosis, and germination, the sexual compatibility within $P$. reticulatum was rather high. Gamete pairs and planozygotes were observed for all clones, together with planozygote division and viability. These observations imply a high level of autocompatibility with respect to gamete recognition and planozygote formation. Although this remains to be confirmed by the detection of nuclear fusion, our results demonstrate that, at least according to their external morphology, planozygotes from self-crosses undergo a division process similar to that of planozygotes from crosses of sexually compatible strains (e.g. PRENM $\times$ PRAY3) and resembling the division of germlings. Therefore, our results suggest that basing mating system type definition on whether syngamy occurs within the same strain (homothallic) or between cells of strains of opposite mating type (heterothallic), P. reticulatum should be considered homothallic.

\subsubsection{Planozygote division}

The division of planozygotes has been documented for several species of dinoflagellates (Uchida, 1991; Uchida et al., 1996; Figueroa et al., 2006a, 2008a; Escalera and Reguera, 2008; Tillmann and Hoppenrath, 2013). Similar to planomeiocyte division, planozygote division in dinoflagellates has been reported as meiotic, with the motile zygotic cells as the unique diplontics (Elbrächter, 2003). While a possible exception was that of 
Noctiluca, reported by Zingmark (1970), who described meiosis in gamete production, this finding was challenged by Schnepf and Drebes (1993), who described a haplontic, and not diplontic life cycle for this species. Nevertheless, recent accumulating evidence pointing to both mitosis and meiosis during planozygote division, which might indicate that the cycle of at least some dinoflagellate species is biphasic rather than haplontic (Tillmann and Hoppenrath, 2013; Figueroa et al., 2015). The detection of meiosis has mainly been based on the observation of nuclear cyclosis, a slow swirling of the nuclear contents first described in dinoflagellates by Pouchet (1883) and later confirmed for other studies of zygotic division (von Stosch, 1972; Parrow and Burkholder, 2004). Yet, meiosis in dinoflagellates remains poorly characterized (Gribble et al., 2009). Zygotic meiosis was cytologically described based on a microfluorimetry study by Bhaud et al. (1988) for Prorocentrum micans and its very unusual pattern was pointed out by SoyerGobillard et al. (2002). Whether zygotic meiosis is a general pattern of the dinoflagellate life cycle must still be determined. The nuclear details of meiosis have been studied only in a few species of these microorganisms but there is as yet no clear evidence that they are representative of dinoflagellate meiosis (Parrow and Burkholder, 2004). Actually there are no proves to totally refuse other type of planozygote division. In a study of $P$. kofoidii, meiotic division was reported to be preceded by mitotic division of the planozygotes (Tillmann and Hoppenrath, 2013), and the authors therefore concluded that this species is diplohaplontic, based on the observation of nuclear cyclosis (indicative of meiosis) in binucleated planozygotes after their first primary division. Other species in which the life cycle of the haploid type is controversial is A. minutum, as a sexual division cycle was recently reported (Figueroa et al., 2015). The cycle followed a diel- and lightdependent rhythm similar to that of the haploid mitotic cycle. In addition to the occurrence of meiosis during planozygote division, the authors suggested mitotic division as well. Support for this claim came from the similarity of the features of the sexual cycle to those of haploid mitosis but also from the presence of longitudinally biflagellated cells immediately after division. The longitudinal biflagellation of daughter cells from the division of a mobile zygote is known for several species of dinoflagellates (Figueroa and Bravo, 2005b; Figueroa et al., 2008b) and was suggested as evidence of the occurrence of mitosis rather than meiosis (Figueroa et al., 2015). Further evidence is provided by our results, specifically, the production of a pair of cells, one longitudinally biflagellated and the other without those flagella at least until de moment of separation, during the first division of both planozygotes and germlings. Nevertheless, more specific determinations of the ploidy level of the cells produced by the division of zygotes and germlings are needed to clarify this issue.

In our study, division of the presumed planozygotes showed at least two patterns: The first was very similar to that of asexual division (desmoschisis), with the parental theca shared by the two daughter cells, one of which retains longitudinal biflagellation. For how long the flagella are retained and whether their presence was simply due to the fact that this daughter cell inherited the flagellar apparatus from the parent were not determined. Attempts to observe the presence and number of flagella of the subsequent progeny were unsuccessful. Investigations on this subject should be undertaken with cytological or genetics methodology since observations of flagellation status is difficult and much timeconsuming. That division pattern was observed in planozygotes (type 1 in Results section) isolated in replete medium. In the isolation wells, the second division of these planozygotes occurred synchronously or asynchronously but eventually always yielded four presumably haploid cells. A second type of division is suggested from the observation of lobed planozygote (type 2 in results) (Fig. 3M-P). They were observed in the crossed strains, mainly during stationary phase. This probable sexual stage presented either one large three-lobed nucleus or three individual nuclei, presumably indicating different levels of nuclear division. The function of this stage, if any, within the cycle is unclear. Asynchronous meiotic division has been documented in the dinoflagellate Peridinium inconspicuum, in which a trinucleate stage (Pfiester, 1984), consisting of one larger nucleus and two small nuclei, was occasionally observed. The three-cell division stage recorded in our study (Fig. $4 \mathrm{~F}$ and $\mathrm{G}$ ) might correspond to that intermediate stage of asynchronous meiotic division described in P. inconspicuum, or to a posterior step of division of the three-lobed planozygote. Whether these cells are intermediate stages during the meiotic division process or culture artifacts due to imperfect divisions requires further study. These nuclear patterns did not occur during the isolating experiment of longitudinally biflagellated cells in replete medium. But, a quadro-lobulated nucleus was documented for planozygotes (1$2 \mathrm{~h}$ after their formation) of the phylogenetically close species $L$. polyedra (Figueroa and Bravo, 2005a).

\subsubsection{Nuclear shape variability in the sexual stages}

Nuclei of the presumed planozygotes of $P$. reticulatum were highly varied in their shape and in some cases their complexity. This made interpretation of the different morphologies and the processes involved extremely difficult. The nuclear forms included U-shaped (open or closed forms), an A-shaped ring, double-rings, round to oval, and lobed. In the case of resting cysts, they also had different nuclear forms. Among them, the U-shaped nucleus presented characteristic dark spots that were also observed in the oval-shaped nucleus of the germling. This feature requires further study to know its meaning, if any. The three-dimensional shapes of the nuclei were readily seen in the video recordings which prevented misinterpretations based on the two-dimensional microscopy images. For instance, the U-shaped nuclei of $P$. reticulatum planozygotes seen in the photographs were actually ring-shaped (see Fig. 3E-H). Ring-shaped and U-shaped nuclei have been reported in planozygotes of $A$. taylorii (Figueroa et al., 2006a). The nuclear forms observed by those authors were similar to those in our study and suggested that A-shaped and ring-shaped nuclei are phases of the nuclear fusion process that occur earlier than the phase represented by the U-shaped nucleus also seen in resting cysts of that species.

\subsubsection{Encystment and dormancy period}

The $P$. reticulatum encystment process began with the formation of a transparent outer membrane on the non-motile planozygote wall. A similar structure was described for $L$. polyedra, another yessotoxin producer, but unlike $P$. reticulatum the outer membrane of this species showed separated thecal plates (Kokinos and Anderson, 1995). In both species, processes of different lengths and forms appeared between the outer membrane and the cell wall. The 10-20 min needed for the complete transition from planozygote to resting cyst in $L$. polyedra, reported by Kokinos and Anderson (1995), was shorter than the 45 min described for $P$. reticulatum. Thereafter, the $P$. reticulatum resting cysts began their maturation period, which was concluded around 4 months later. Benthic cysts of $P$. reticulatum exhibited all the morphological characteristics already described for this species in earlier studies (Matsuoka et al., 1997; Nehring, 1997; Akselman et al., 2015). Relatively similar ( $\sim 3$ months) periods of dormancy have been documented for A. catenella from Japan and Australia (Yoshimatsu, 1984; Hallegraeff et al., 1998), for L. polyedra (2-4 months) (Figueroa and Bravo, 2005b), and for A. taylorii (2-3 months) (Figueroa et al., 2006a) whereas the maturation of Alexandrium tamutum and $A$. minutum is concluded within $<20$ days and $1-1.5$ months, respectively (Figueroa et al., 2007). The dormancy period 
for $P$. reticulatum suggests that benthic resting cysts play an important role in the ecology of this species, shaping benthic overwintering populations in areas where the climatic conditions in winter are unfavorable for population growth, as is the case in the channels and fjords of southern Chile (Guzmán et al., 2011). Nevertheless, the dormancy period might be different for other $P$. reticulatum populations from other geographical regions.

\section{Acknowledgements}

The authors thank Pilar Rial and Elena Fagin for technical support. Gemita Pizarro from Instituto de Fomento Pesquero (IFOP) for providing the $P$. reticulatum strains. Inés Pazos from CACTI, University of Vigo, for SEM microscopy. The present work was funded by the CCVIEO project and the Spanish National Project CICAN (CGL2013-40671-R). The Red Tide Monitoring Program of Southern Chile during which strains were isolated, was funded by the Subsecretaría de Pesca y Acuicultura (SUBPESCA) of the Ministerio de Economía, Fomento y Turismo and carried out by IFOP. This article will be part of the doctoral thesis of Pablo Salgado and is within the doctoral program "Marine Science, Technology and Management" (DO*MAR) of the University of Vigo. Pablo Salgado is a researcher at the IFOP, which has provided financial support for his doctoral stay at the Instituto Español de Oceanografía (IEO) in Vigo.[SS]

\section{Appendix A. Supplementary data}

Supplementary data associated with this article can be found, in the online version, at http://dx.doi.org/10.1016/j.hal.2017.07.008.

\section{References}

Álvarez, G., Uribe, E., Díaz, R., Braun, M., Mariño, C., Blanco, J., 2011. Bloom of the Yessotoxin producing dinoflagellate Protoceratium reticulatum (Dinophyceae) in Northern Chile. J. Sea Res. 65, 427-434.

Akselman, R., Krock, B., Alpermann, T., Tillmann, U., Borel, M., Almandoz, G., Ferrario, M., 2015. Protoceratium reticulatum (Dinophyceae) in the austral Southwestern Atlantic and the first report on YTX-production in shelf waters of Argentina. Harmful Algae 45, 40-52.

Alves-de-Souza, C., Varela, D., Navarrete, F., Fernández, P., Leal, P., 2008. Distribution, abundance and diversity of modern dinoflagellate cyst assemblages from southern Chile (43-54 S). Bot. Mar. 51, 399-410.

Bhaud, Y., Soyer-Gobillard, M.O., Salmon, J.M., 1988. Transmission of gametic nuclei through a fertilization tube during mating in a primitive dinoflagellate Prorocentrum micans Ehr. J. Cell Sci. 89, 197-206.

Blackburn, S.I., Bolch, C.J., Haskard, K.A., Hallegraeff, G.M., 2001. Reproductive compatibility among four global populations of the toxic dinoflagellate Gymnodinium catenatum (Dinophyceae). Phycologia 40 (1), 78-87.

Braarud, T., 1945. Morphological observations on marine dinoflagellate cultures (Porella perforata, Goniaulax tamarensis, Protoceratium reticulatum). Avh. Norske Videnskakad. Oslo Mat.-nat. Kl. 11 (11), 1-18.

Bravo, I., Figueroa, R.I., 2014. Toward an ecological understanding of dinoflagellate cysts funtions. Microorganisms 2, 11-32.

Brosnahan, M.L., Farzan, S., Keafer, B., Sosik, H.M., Olson, R.J., Anderson, D.M., 2014. Complexities of bloom dynamics in the toxic dinoflagellate Alexandrium fundyense revealed through DNA measurements by imaging flow cytometry coupled with species-specific rRNA probes. Deep Sea Res. 2 Top. Stud. Oceanogr. 103, 185-198.

Ciminiello, P., Dell-Aversano, C., Fattorusso, E., Forino, M., Magno, S., Guerrini, F., Pistocchi, R., Boni, L., 2003. Complex yessotoxins profile in Protoceratium reticulatum from north-western Adriatic sea revealed by LC-MS analysis. Toxicon 42, 7-14.

Dagenais-Bellefeuille, S., Bertomeu, T., Morse, D., 2008. S-phase and M-phase timing are under independent circadian control in the dinoflagellate Lingulodinium. J. Biol. Rhythms 23, 400-408.

Dale, B., 1983. Dinoflagellate resting cysts: benthic plankton. In: Fryxell, G.A. (Ed.), Survival Strategies of the Algae. Cambridge University Press, New York, pp. 69136.

Dapena, C., Bravo, I., Cuadrado, A., Figueroa, R.I., 2015. Nuclear and cell morphological changes during the cell cycle and growth of the toxic dinoflagellate Alexandrium minutum. Protist 166, 146-160.

Destombe, C., Cembella, A., 1990. Mating-type determination, gametic recognition and reproductive succes in Alexandrium excavatum (Gonyaulacales, Dinophyta), a red-tide dinoflagellate. Phycologia 29 (3), 316-325.
Elbrächter, M., 2003. Dinophyte reproduction: progress and conflicts. J. Phycol. 39, 629-632.

Escalera, L., Reguera, B., 2008. Planozygote division and other observations on the sexual cycle of several species of Dinophysis (Dinophyceae, Dinophysiales). J. Phycol. 44, 1425-1436.

Figueroa, R., Bravo, I., 2005a. A study of the sexual reproduction and determination of mating type of Gymnodinium nolleri (Dinophyceae) in culture. J. Phycol. 41, $74-83$.

Figueroa, R.I., Bravo, I., 2005b. Sexual reproduction and two different encystment strategies of Lingulodinium polyedrum (Dinophyceae) in culture. J. Phycol. 41, 370-379.

Figueroa, R., Bravo, I., Garcés, E., 2006a. Multiple routes of sexuality in Alexandrium taylori (Dinophyceae) in culture. J. Phycol. 42, 1028-1039.

Figueroa, R.I., Bravo, I., Garcés, E., Ramilo, I., 2006b. Nuclear features and effect of nutrients on Gymnodinium catenatum (Dinophyceae) sexual stages. J. Phycol. 42 (1), 67-77.

Figueroa, R.I., Garces, E., Bravo, I., 2007. Comparative study of the life cycles of Alexandrium tamutum and Alexandrium minutum (Gonyaulacales, Dinophyceae) in culture. J. Phycol. 43, 1039-1053.

Figueroa, R.I., Bravo, I., Garcés, E., 2008a. The significance of sexual versus asexual cyst formation in the life cycle of the noxious dinoflagellate Alexandrium peruvianum. Harmful Algae 7, 653-663.

Figueroa, R.I., Bravo, I., Ramilo, I., Pazos, Y., Moroño, A., 2008b. New life-cycle stages of Gymnodinium catenatum (Dinophyceae): laboratory and field observation. Aquat. Microb. Ecol. 52, 13-23.

Figueroa, R.I., Dapena, C., Bravo, I., Cuadrado, A., 2015. The hidden sexuality of Alexandrium minutum: an example of overlooked sex in dinoflagellates. PLoS One 10 (11), e0142667.

Fraga, S., Rodríguez, F., Caillaud, A., Diogène, J., Raho, N., Zapata, M., 2011. Gambierdiscus excentricus sp. nov. (Dinophyceae): a benthic toxic dinoflagellate from the Canary Islands (NE Atlantic Ocean). Harmful Algae 11, 10-22.

Fritz, L., Triemer, R.E., 1985. A rapid simple technique utilizing Calcoflour White M2R for the visualization of dinoflagellate thecal plates. J. Phycol. 21, 662-664.

Giacobbe, M.G., Yang, X., 1999. The life history of Alexandrium taylori (Dinophyceae). J. Phycol. 35, 331-338.

Gribble, K., Anderson, D.M., Coats, W., 2009. Sexual and asexual processes in Protoperidinium steidingerae Balech (Dinophyceae), with observations on lifehistory stages of Protoperidinium depressum (Bailey) Balech (Dinophyceae). J. Eukaryot. Microbiol. 56 (1), 88-103.

Guillard, R.R.L., Hargraves, P.E., 1993. Stichochrysis immobilis is a diatom, not achrysophyte. Phycologia 32, 234-236.

Guzmán, L., Vidal, G., Pizarro, G., Vivanco, X., Iriarte, L., Alarcón, C., Arenas, V., Mercado, S., Pacheco, H., Mejías, P., Salgado, P., Palma, M., Espinoza, C., Fernández-Niño, E., Monsalve, J., Zamora, C., Hinojosa, P., 2011. Manejo y monitoreo de las mareas rojas, en las regiones de Los Lagos, Aysén y Magallanes. IV Etapa, 2009-2010., Convenio Asesoría integral para la pesca y la acuicultura (ASIPA). Subsecretaría de Economía y empresas de menor tamaño-Instituto de Fomento Pesquero, 16 pp + Figuras + Tablas + Anexos.

Guzmán, L., Vidal, G., Pizarro, G., Espinoza, O., Vivanco, X., Iriarte, L., Mercado, S., Pacheco, H., Alarcón, C., Labra, G., López, L., Calderón, M., Tardón, H., Muñoz, V., Mellado, C., Cornejo, M.F., Toro, C., Palma, M., Monsalve, J., Fernández-Niño, E., Espinoza, C., 2015. Programa de manejo y monitoreo de las mareas rojas en las regiones de Los Lagos, Aysén y Magallanes, Etapa VIII 2014-15. Tomo I y II, Convenio Desempeño 2014. Subsecretaría de Economía y empresas de menor tamaño (EMT)-Instituto de Fomento Pesquero, 187 pp + Figuras + Tablas + Anexos.

Hallegraeff, G., Marshall, J.A., Valentine, J., Hardiman, S., 1998. Short cyst-dormancy period of an Australian isolate of the toxic dinoflagellate Alexandrium catenella. Mar. Freshwater Res. 49, 415-420.

Hansen, G., Moestrup, Ø., Roberts, K.R., 1996/97. Light and electron microscopical observations on Protoceratium reticulatum (Dinophyceae). Arch. Protistenkd. $147,381-391$.

Hoppenrath, M., Schweikert, M., Elbrächter, M., 2003. Morphological reinvestigation and characterization of the marine: sand-dwelling dinoflagellate Adenoides eludens (Dinophyceae). Eur. J. Phycol. 38, 385-394.

Jansson, I.M., Mertens, K.N., Head, M.J., 2014. Statistically assessing the correlation between salinity and morphology in cysts produced by the dinoflagellate Protoceratium reticulatum from surface sediments of the North Atlantic Ocean, Mediterranean-Marmara-Black Sea region, and Baltic-Kattegat-Skagerrak estuarine system. Palaeogeogr. Palaeoclimatol. Palaeoecol. 399, 202-213.

Kokinos, J.P., Anderson, D.M., 1995. Morphological development of resting cysts in cultures of the marine dinoflagellate Lingulodinium polyedrum (=L. machaerophorum). Palynology 19, 143-166.

Kremp, A., 2000. Morphology and germination pattern of the resting cyst of Peridiniella catenata (Dinophyceae) from the Baltic Sea. Phycologia 39, 183-186.

Matsuoka, K., McMinn, A., Wrenn, J., 1997. Restudy of the holotype of Operculodinium centrocarpum (Deflandre \& Cookson) wall (Dinophyceae) from the miocene of Australia, and the taxonomy of related species. Palynology 21, 19-33.

McLachlan, J.L., 1993. Evidence for sexuality in a species of Dinophysis. In: Smayda, T. J., Shimizu, Y. (Eds.), Toxic Phytoplankton Blooms in the Sea. Proceedings of the Fifth International Conference on Toxic Marine Phytoplankton. Elsevier Science Publishers B.V., Amsterdam, pp. 143-146.

Mertens, K.N., Dale, B., Ellegaard, M., Jansson, I.M., Godhe, A., Kremp, A., Louwye, S., 2011. Process length variation in cysts of the dinoflagellate Protoceratium 
reticulatum, from surface sediments of the Baltic-Kattegat-Skagerrak estuarine system: a regional salinity proxy. Boreas 40, 242-255.

Montresor, M., John, U., Beran, A., Medlin, L., 2004. Alexandrium tamutum sp. nov. (Dinophyceae): a new nontoxic species in the genus Alexandrium. J. Phycol. 40, 398-411.

Murata, M., Kumagai, M., Lee, J.-S., 1987. Isolation and structure of yessotoxin: a novel polyether compound implicated in diarrhetic shellfish poisoning. Tetrahedron Lett. 28, 5869-5872.

Nehring, S., 1997. Dinoflagellate resting cysts from recent german coastal sediments. Bot. Mar. 40, 307-324.

Parrow, M., Burkholder, J., 2004. The sexual life cycles of Pfiesteria piscicida and cryptoperidiniopsid (Dinophyceae). J. Phycol. 40, 664-673.

Paz, B., Riobó, P., Fernández, M.L., Fraga, S., Franco, J.M., 2004. Production and release of yessotoxins by the dinoflagellates Protoceratium reticulatum and Lingulodinium polyedrum in culture. Toxicon 44, 251-258.

Paz, B., Riobó, P., Ramilo, I., Franco, J.M., 2007. Yessotoxins profile in strains of Protoceratium reticulatum from Spain and USA. Toxicon 50, 1-17.

Pfiester, L.A., Anderson, D.M., 1987. Dinoflagellate reproduction. In: Taylor, F.J.R (Ed.), The Biology of the Dinoflagellates. Blackwell Oxford, Bot. Monogr pp. 21, 611-648.

Pfiester, L.A., 1984. Sexual reproduction. In: Spector, D.L. (Ed.), Dinoflagellates. Academic Press, New York, pp. 181-199.

Pouchet, G., 1883. Contribution á l'histoire des Cilio-flagelles. J. Anat. Physiol. Norm. Pathol. Homme Amin. 19, 399-455.

Ramstad, H., Hovgaard, P., Yasumoto, T., Larsen, S., Aune, T., 2001. Monthly variations in diarrhetic toxins and yessotoxin in shellfish from coast to the inner part of the Sognefjord, Norway. Toxicon 39, 1035-1043.

Reinecke, P., 1967. Gonyaulax grindleyi sp. nov.: a dinoflagellate causing a red tode at Elands Bay, Cape Province, in December 1966. S. Afr. J. Bot. 33 (3), 157-160.

Sala-Pérez, M., Alpermann, T.J., Krock, B., Tillmann, U., 2016. Growth and bioactive secondary metabolites of artic Protoceratium reticulatum (Dinophyceae). Harmful Algae 55, 85-96.

Salgado, P., Fraga, S., Rodríguez, F., Bravo, I., Benthic flattened cells of the phylogenetically related marine dinoflagellates Protoceratium reticulatum and Ceratocorys mariaovidii (Gonyaulacales): A new type of cyst? (submitted).

Satake, M., Mackenzie, L., Yasumoto, T., 1997. Identification of Protoceratium reticulatum as the biogenetic origin of yessotoxin. Nat. Toxins 5, 164-167.

Satake, M., Ichimura, T., Sekiguchi, K., Yoshimatsu, S., Oshima, Y., 1999. Confirmation of yessotoxin and 45,46,47-trinoryessotoxin production by Protoceratium reticulatum collected in Japan. Nat. Toxins 7, 147-150.

Schnepf, E., Drebes, G., 1993. Anisogamy in the dinoflagellate Noctiluca? Helgoländer Meeresunters. 47, 265-273.

Seguel, M., Sfeir, A., 2010. Distribución de las toxinas y quistes de dinoflagelados tóxicos en los canales occidentales de la Región de Aysén. Cienc. Tecnol. Mar. 33 (1), 43-55.

Seguel, M., Sfeir, A., Alvornoz, V., Gangas, M., Molinet, C., Díaz, P., 2010. Distribución de los quistes de Alexandrium catenella y Protoceratium reticulatum (Dinophyceae) en la región Sur-Austral de Chile. Cienc. Tecnol. Mar. 33 (2), 59-70.
Sildever, S., Andersen, T.J., Ribeiro, S., Ellegaard, M., 2015. Influence of surface salinity gradient on dinoflagellate cyst community structure, abundance and morphology in the Baltic Sea, Kattegat and Skagerrak. Estuar. Coast. Shelf Sci. $155,1-7$.

Soyer-Gobillard, M.O., Bhaud, Y., Saint Hilaire, D., 2002. New data on mating in an autotrophic dinoflagellate, Prorocentrum micans Ehrenberg. Vie Milieu 52, 167175.

Stobo, L.A., Lewis, J., Quilliam, M.A., Hardstaff, W.R., Gallacher, S., Webster, L., Smith, E., McKenzie, M., 2003. Detection of yessotoxin in UK and Canadian isolates of phytoplankton and optimization and validation of LC-MS methods. In: Bates, S. (Ed.), Eighth Canadian Workshop on Harmful Marine Algae. Gulf Fisheries Centre, Moncton, New Brunswick, Canada, pp. 8-14.

Suzuki, T., Horie, Y., Koike, K., Satake, M., Oshima, Y., Iwataki, M., Yoshimatsu, S., 2007. Yessotoxin analogues in several strains of Protoceratium reticulatum in Japan determined by liquid chromatography-hybrid triple quadrupole/linear ion trap mass spectrometry. J. Chromatogr. A 1142, 172-177.

Taroncher-Oldenburg, G., Kulis, D.M., Anderson, D.M., 1997. Toxin variability during the cell cycle of the dinoflagellate Alexandrium fundyense. Limnol. Oceanogr. 42, $1178-1188$.

Tillmann, U., Hoppenrath, M., 2013. Life cycle of the pseudo colonial dinoflagellate Polykrikos kofoidii (Gymnodiniales, Dinoflagellata). J. Phycol. 49 (2), 298-317.

Uchida, T., Matsuyama, Y., Yamaguchi, M.T.H., 1996. The life cycle of Gyrodinium instriatum (Dinophyceae) in culture. Phycological Res. 44 (3), 119-123.

Uchida, T., 1991. Sexual reproduction of Scrippsiella trochoidea isolated from Muroran Harbor, Hokkaido. Nippon Suisan Gakk. 57, 1215.

Verleye, T.J., Mertens, K.N., Young, M.D., Dale, B., McMinn, A., Scott, L., Zonneveld, K. A.F., Louwye, S., 2012. Average process length variation of the marine dinoflagellate cyst Operculodinium centrocarpum in the tropical and Southern Hemisphere Oceans: assessing its potential as a palaeosalinity proxy. Mar. Micropaleontol. 86 (-87), 45-58.

Wall, D., Dale, B., 1968. Modern dinoflagellate cysts and evolution of the peridiniales. Micropaleontology 14 (3), 265-304.

Wall, D., 1967. Fossil microplankton in deep-sea cores from the Caribbean Sea. Palaeontology 10, 95-123.

Yasumoto, T., Takizawa, A., 1997. Fluorometric measurement of yessotoxins in shellfish by high-pressure liquid chromatography. Biosci. Biotechnol. Biochem. 61, 1775-1777.

Yoshimatsu, S., 1981. Sexual reproduction of Protogonyaulax catenella in culture. Bull. Plankton Soc. Jpn. 28, 131-139.

Yoshimatsu, S., 1984. Sexual reproduction of Protogonyaulax catenella in culture. 2. Determination of mating type. Bull. Plankton Soc. Jpn. 31, 107-111.

Zingmark, R.G., 1970. Sexual reproduction in the dinoflagellate Noctiluca miliaris Suriray. J. Phycol. 6 (2), 122-126.

von Stosch, H.A., 1972. La signification cytologique de la cyclose nucléaire dans le cycle de vie des Dinoglagellés. Mem. Soc. Bot. Fr. (1949-1973) 201-212.

von Stosch, H.A., 1973. Observations on vegetative reproduction and sexual life cycles of two freshwater dinoflagellates, Gymondinium pseudopalustre Schiller and Woloszynskia apiculata sp nov. Eur. J. Phycol. 105-134. 